IZA DP No. 7379

Gender Differences in Sickness Absence and the Gender Division of Family Responsibilities

Nikolay Angelov

Per Johansson

Erica Lindahl

April 2013 


\title{
Gender Differences in Sickness Absence and the Gender Division of Family Responsibilities
}

\author{
Nikolay Angelov
}

IFAU and UCLS

Per Johansson

IFAU, Uppsala University and IZA

Erica Lindahl

IFAU

Discussion Paper No. 7379

April 2013

IZA

P.O. Box 7240

53072 Bonn

Germany

Phone: +49-228-3894-0

Fax: +49-228-3894-180

E-mail: iza@iza.org

Any opinions expressed here are those of the author(s) and not those of IZA. Research published in this series may include views on policy, but the institute itself takes no institutional policy positions. The IZA research network is committed to the IZA Guiding Principles of Research Integrity.

The Institute for the Study of Labor (IZA) in Bonn is a local and virtual international research center and a place of communication between science, politics and business. IZA is an independent nonprofit organization supported by Deutsche Post Foundation. The center is associated with the University of Bonn and offers a stimulating research environment through its international network, workshops and conferences, data service, project support, research visits and doctoral program. IZA engages in (i) original and internationally competitive research in all fields of labor economics, (ii) development of policy concepts, and (iii) dissemination of research results and concepts to the interested public.

IZA Discussion Papers often represent preliminary work and are circulated to encourage discussion. Citation of such a paper should account for its provisional character. A revised version may be available directly from the author. 


\section{ABSTRACT}

\section{Gender Differences in Sickness Absence and the Gender Division of Family Responsibilities}

This study investigates possible reasons for the gender difference in sickness absence. We estimate both short- and long-term effects of parenthood in a within-couple analysis based on the timing of parenthood. We find that after entering parenthood, women increase their sickness absence by between 0.5 days per month (during the child's third year) and 0.85 days per month (during year 17) more than their spouse. By investigating possible explanations for the observed effect, we conclude that the effect mainly stems from higher home commitment, which reduces women's labour market attachment and, in turn, increases female sickness absence.

JEL Classification: $\quad$ C23, D13, I19, J22

Keywords: double burden, health investment, household work, labour market work, moral hazard, parenthood, sickness insurance, work absence

Corresponding author:

Per Johansson

IFAU

Box 513

75120 Uppsala

Sweden

E-mail: per.johansson@ifau.uu.se

\footnotetext{
* We are grateful for comments during seminars at IFAU, UCLS, and the Ministry of Social Affairs, as well as from participants at the Workshop on absenteeism and social insurance (Utrecht, September 2011). Financial support from the Swedish Council for Working Life and Social Research (DNR 20042005) is gratefully acknowledged.
} 


\section{Introduction}

Women are more absent from work for health reasons than men (see e.g., Paringer, 1983; Broström et al., 2004; Mastekaasa and Olsen, 1998, and Bratberg et al., 2002). This observation is in line with other observed gender differences on morbidity measures such as health care utilization and self reported health (see e.g., Sindelar, 1982). One interesting aspect of the gender difference in work absence for health reasons, denoted sickness absence in the following, is its strong correlation over time with the gender difference in labor supply (see Figure 3 in section 2). This provides suggestive evidence that the gender difference is not primarily driven by health differences, but rather connected to the increased female labor supply over the last 40 years. ${ }^{1}$

Today, the dual earner family is the most common family form in the OECD countries. ${ }^{2}$ Family responsibilities are, however, not equally shared; instead, women tend to perform dual tasks (see e.g. Boye, 2008; Booth and Ours, 2005; Evertsson and Nermo, 2007; Tichenor, 1999). Women are active on the labour market and they perform the majority of the household production, while men predominantly specialize in market work. More effort at home would in general mean less time and effort for labour market work. This is also what we observe. Time use studies in Sweden have consistently shown that labour market work is higher for men but that total time worked (household and labour market) of men and women are approximately the same (SCB, 2009). This result corresponds well with time-use studies in USA, Germany and the Netherlands (Burda et al., 2008).

It is also empirically established that the unequal gender division of household and market work emerges when couples get their first child (Van der Lippe and Siegers, 1994; Sanchez and Thomson 1997, Gauthier and

\footnotetext{
${ }^{1}$ The global average gender gap in life expectancy is four years (cf. Lee, 2010) and in Sweden the gap is almost 5 years (The World Factbook, 2012). This observed morbiditymortality paradox (see also Nathanson, 1975 and Verbrugge, 1982) is also in line with the idea that the gender gap in sickness absence is not primarily driven by gender health differences.

${ }^{2}$ The median employment rate for partnered mothers in the OECD countries was 66.5 percent in 2007 (OECD 2010) and according to U.S. Bureau of Labor Statistics (2011), the U.S. labor force participation rate of mothers with children under 18 years of age was 71.3 percent in March 2010 .
} 
Furstenberg, 2002; Gjerdingen and Center 2005; Baxter et al. 2008) and that women decrease their labor supply after childbirth (e.g., Angrist and Evans, 1998 and Jacobsen, Wishart, and Rosenbloom, 1999) while fathers, if anything, even do the opposite (Kennerberg, 2007).

From this perspective it is of interest to study the effects of the unequal sharing of the new commitment at home after becoming parents, or in other words, to study the effects of women's dual role on different outcomes. This paper studies whether there is a gender difference in the effect of parenthood on sickness absence behaviour. To this end, we compare the evolution of the within-couple gender gap in sickness absence before and after the arrival of the first child. The empirical analysis is based on detailed universal Swedish administrative registers. These data allow us to track parents' sickness absence $^{3}$ over a significant part of their labour market career, starting a few years before parenthood up to 18 years after the arrival of the first child.

To our knowledge, this is the first study of the effect of parenthood on sickness absence. A related study is Åkerlind et al. (1996), who estimate gender differences in sickness absence at different ages separately for individuals with and without children. More closely related are two studies that focus on the effect of household responsibility on sickness absence. Bratberg et al. (2002) suggest that the gender gap in sickness absence stems from the psychological pressure of the dual role, or in other words, what they denote a double burden among women. In their empirical analysis, Bratberg et al. (2002) use the number of children as a proxy for family responsibilities. Paringer (1983), on the other hand, argues that women's dual role as both producers on the labour market and at home (in contrast to the more labour market specialized man) implies that women's health is more important for the household than men's, since a household would suffer more than just forgone earnings if the female is ill. In the empirical analysis, Paringer uses marital status as a proxy for household responsibilities and finds that, married women are less absent from work for health

\footnotetext{
${ }^{3}$ Sickness absence is defined as days with sickness benefits paid by the Swedish Social Insurance Agency. The first two weeks are paid for by the employer if the insured individual is employed. The length of the employer-payment period has varied over time from 2 to 3 weeks. In all estimations we control for this variation over time with year dummies.
} 
reasons than unmarried women, contrary to what theory predicts.

Estimating a causal effect of family responsibilities on sickness absence by using marital status or number of children as proxy variables is associated with methodological challenges. The basic problem is to separate the effects of marital status or number of children from potentially correlated factors that also might affect sickness absence. Marital status and the number of children are both positively correlated with household responsibilities, but they are probably also correlated with health; women who are married or have (many) children at a given age probably have better health and might thereby be less absent due to sickness than non-married women or women without (or with few) children.

In this study, we take advantage of detailed register data, which allow us to use the timing of parenthood in the identification of both shortand long-term effects of parenthood on sickness absence. By focusing on the within-couple difference over time, we do not have to rely on crosssectional comparisons and we control for both observed and unobserved factors correlated with parenthood and sickness absence.

Our main finding is that entering parenthood on average increases mothers' sickness absence in comparison with fathers'. Before the arrival first child, there is no significant difference between the genders. During the child's third year, when most of the mothers are back at work, women are about 0.5 days per month more absent due to own sickness than men. This gender gap persists and gradually increases as long as data allow us to follow the parents, i.e., 17 years after the first born child's birth, when the gender gap is about 0.85 days per month. This result holds for several sensitivity analyses, including different model specifications, controlling for subsequent births and restricting the sample in various ways with respect to the maximum number of children and the income level of the parents. A graphical analysis suggests that the effect stems from an increase in sickness absence among women and no corresponding increase among men.

We discuss two possible explanations for the observed gender differences in sickness absence after parenthood. The first explanation focuses on gender differences in health. On the one hand, physiological pressure among women due to their dual responsibility (cf. Bratberg et al., 2002) may cause health deterioration. On the other hand, this dual responsibility 
may lead to an increased investment in health, as suggested by Paringer (1983), thereby causing a relative improvement in female health. The second explanation concerns changes in economic incentives for labour market work after entering parenthood. The conclusion from an analysis of this explanation is that reduced labour market attachment among women after entering parenthood is an important explanatory factor for the gender gap in sickness absence.

This paper is organized as follows. Section 2 provides some background information about the development on the Swedish labour market during the latest decades with respect to sickness absence and labour market participation. Section 3 describes the Swedish social insurance system. Section 4 formalizes the empirical framework and gives some basic descriptive statistics and some first-glance graphical evidence. Section 5 presents the main results and in section 6 , we discuss and present empirical evidence for possible explanations for the observed gender differences. Finally, section 7 concludes the paper.

\section{The gender gap in sickness absence and labour supply}

Figure 1 presents the average number of days replaced by sickness benefits among Swedish men and women from the day the Swedish public sickness insurance was introduced (i.e., year 1955) until today. The figure shows that there has not always been a female-male gap in sickness absence. The gap started in the 1980s. Before the 1980s, the gap was small and even in the opposite direction for some years.

The evolution of the gender gap in sickness absence is associated with the evolution of the female labour force participation rate. Before 1980, the female labour force participation rate was significantly below men's. In 1970 , the employment rate among women was 65 percent of the employment rate among men and in 1990 the corresponding number was 90 percent (OECD, 2004). ${ }^{4}$

\footnotetext{
${ }^{4}$ This rapid increase in the female labour force participation can partly be explained by a change in the Swedish tax system. In 1971, Swedish married couples started to
} 


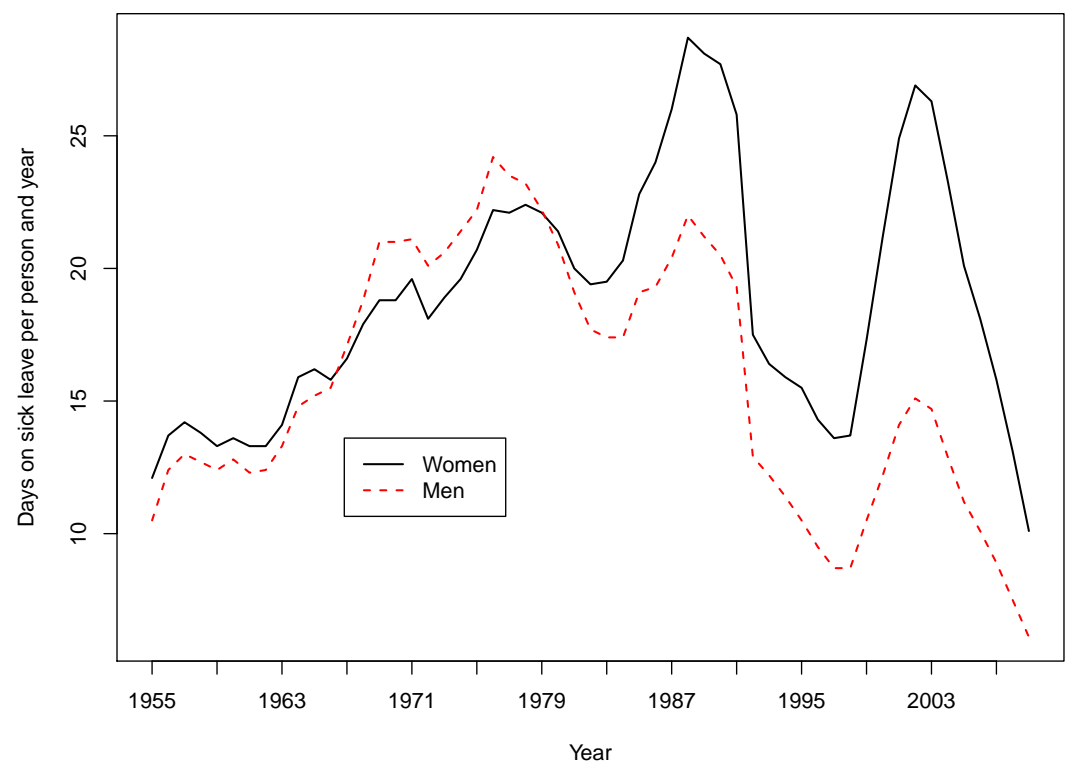

Figure 1: The average number of sick-leave days with sickness benefits per person (ages 16-65) and year in Sweden, divided upon men and women. Source: Statistics Sweden.

Although we lack exact information on which group of women that entered the labour market in the 1960s and in the 1970s, several facts suggest that it was, at least partly, driven by mothers with young children. During the 1970s and 1980s, the Swedish parental leave system became more generous and the public provided child-care expanded rapidly. Figure 2 shows the employment rate between 1976 and 2004 among women in general and among women with children less than 7 years of age, respectively. The female labour force participation increased with 10 percentage points between the mid 1970s and the climax of the Swedish economic boost in 1990. Among women with pre-school children the increase was about twice as large: almost 20 percentage points. From 1990 onwards, the labour force participation among Swedish women with pre-school children has been even higher than the corresponding number among Swedish women in general.

be taxed separately rather than together, implying that the marginal tax rate that many Swedish wives faced decreased and, hence, their incentives for labour market work increased. Selin (2009) has studied the labour supply effects of this reform and he concludes that the female labour supply increased by 10 percentage points due to the reform. 


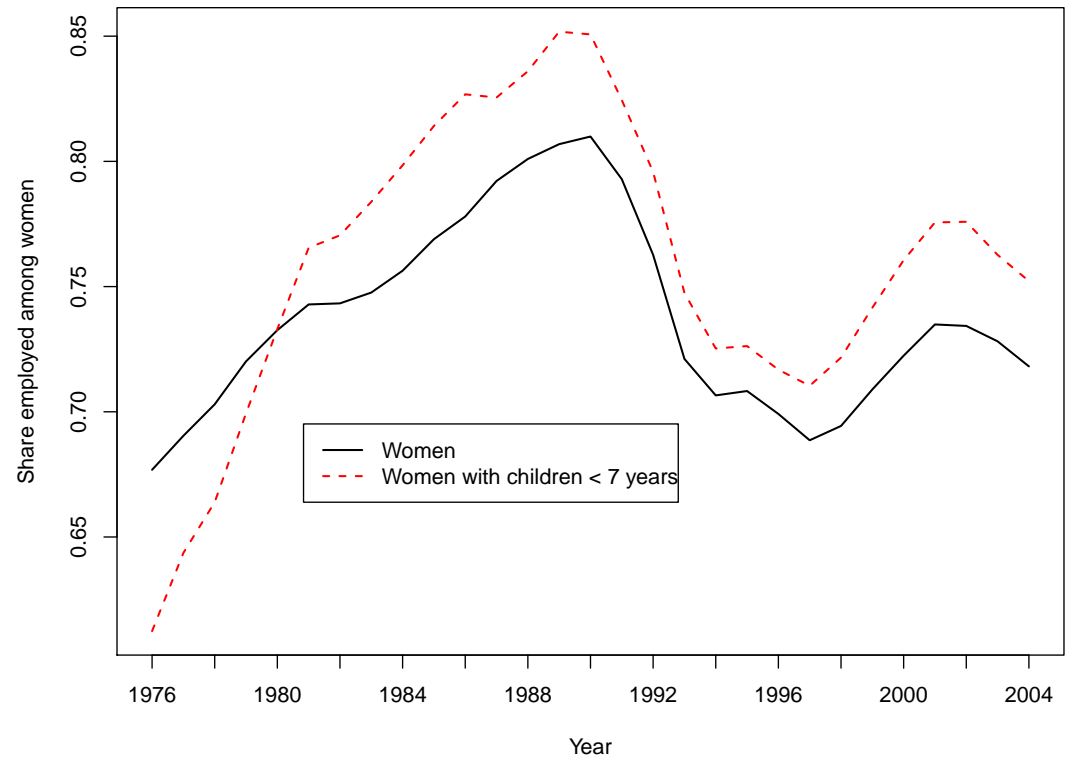

Figure 2: Labor force participation among all Swedish women and among women with children under 7 years between 1976 and 2004. Source: Statistics Sweden.

Source: Statistics Sweden.

This pattern is most likely due to the fact that almost all young women participate in the labour force, while house-wives still exists among older women. In this context it is also interesting to note that the share of Swedish full-time working women has increased from 30 percent in 1980 to 50 percent in 2007 (see Angelov, Johansson, Lindahl och Lindström, 2011).

Cross-country data on male and female sickness absence and labour supply suggests that the gender gap in sickness absence is associated with the increased female labour force participation. Figure 3 presents the femalemale gap in sickness absence in eight different European countries and Figure 4 shows the labour force participation rate among women in the same countries. The Nordic countries (Sweden, Norway and Denmark) have a high share of women participating in the labour force and these countries are also among the top with respect to the gender gap in sickness absence. In contrast, Germany has a relatively low labour force participation rate among women and also a low gender gap in sickness absence. ${ }^{5}$

\footnotetext{
${ }^{5}$ The low female labour force participation rate in Germany could partly be related
} 


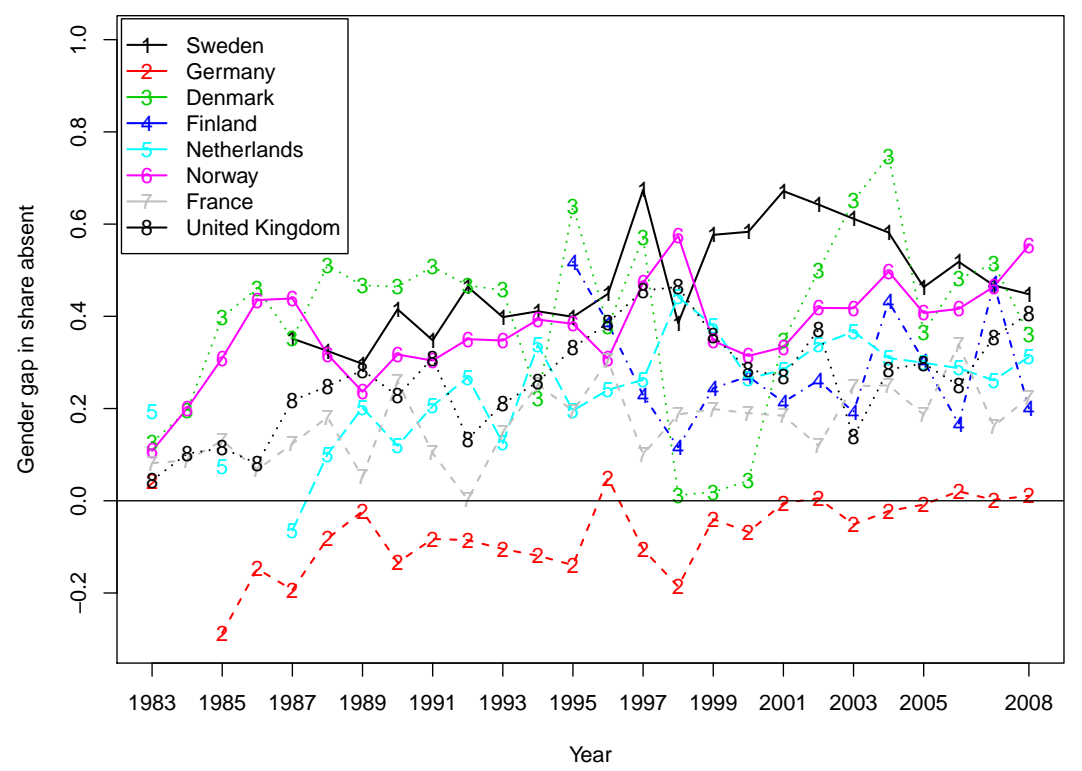

Figure 3: i) The percentage female-male gap in sickness absence during a study-period of one week among employed workers in eight European countries.

Source: Eurostat.

Swedish women do not leave the labour market when they enter parenthood. However, they do take the large majority of the parental leave and they utilize the generous Swedish parental leave system and work part-time while having small children. In Sweden, 80 percent of the paid parental leave is taken by women (Försäkringskassan, 2011) ${ }^{6}$ and 44 percent of all women in the ages $25-54$ work part-time ( $<35$ hours per week). ${ }^{7}$ The corresponding share of men who work part-time is 10 percent.

to the fact that married couples in Germany still are taxed together.

${ }^{6}$ During the first 18 months with a baby both parents can stay at home on a full-time basis with job-protection. Thereafter, parents are allowed to reduce their working hours up to 25 percent until the child turns 8 years old (SFS 1995:584).

${ }^{7}$ Public statistics from Statistics Sweden, published on the web: http://www.scb. se/Pages/Article_--_332715.aspx 


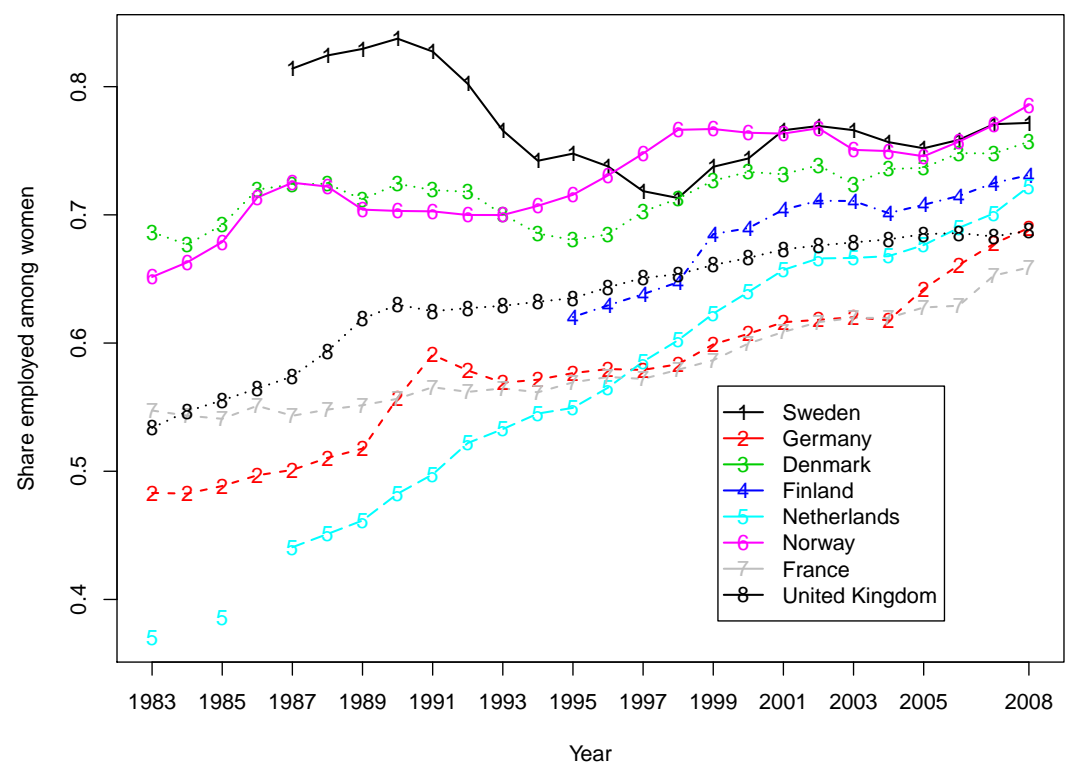

Figure 4: The share employed among women in eight European countries. Source: Eurostat.

\section{The Swedish social insurance}

All residents aged 16 and over in Sweden are registered at the Social Insurance Agency (SIA). Workers (employed and unemployed) are entitled to sickness benefits in case of own sickness, as well as to paid parental leave and temporary parental benefits in case of child illness. In this section we briefly explain the Swedish social insurance system and the entitlements for these benefits.

\subsection{General principles}

The rules for entitlement have changed over time but the general idea has always been that both the employed and the unemployed are entitled a replacement that is proportional to forgone earnings up to a cap. The replacement rate has varied over time between 75 and 90 percent of forgone earnings up to a limit equal to yearly earnings of about 7.5 basic amounts (which in 2009 corresponded to earnings in the 70th percentile of the earn- 
ings distribution). ${ }^{8}$ The time limit for how many days an individual can receive compensation from the SIA depends on the reason for the absence.

\subsection{Sickness benefits}

In case of illness, the first day is not replaced. Thereafter the employer pays sick-pay for the 14 following days. After 14 days the SIA disburses sickness benefits. For unemployed persons the SIA starts disbursing sickness benefits from the second day onwards. In this study, we focus on sickness absence with sickness benefit. That means that for employees, we start counting the number of days absent from the first day in the third week within a given illness period. (For unemployed persons we start counting the second day in a sick-spell, i.e., when the SIA enters.) Thus, the type of sickness absence we have in mind in this study is not short-term sickness absence but a longer-lasting reduced working capacity (usually longer than 14 days) ${ }^{9}$

Compensation for illness periods longer than 7 days requires a medical certificate from a physician with information about the expected length of the sick leave. Based on this certificate, the SIA formally decides whether an individual is entitled compensation or not. When the entitled period has expired, a renewal certificate is required and the process is repeated. A person can be on sickness benefit for at most 364 days during 15 months. If work capacity is still reduced after a year, a person can apply for extended sickness benefit, which could, at the time, continue without time limit. ${ }^{10}$

Although the formal decision about sickness benefits is made by the SIA, the sickness benefit claimant can influence the outcome. According to Arrelöv et al. (2006), the outcome is largely controlled by the insured's motivation. Englund (2001) also finds that doctors believe that they prescribe too long sickness-absence durations, that is, the duration is not always motivated by medical consideration.

\footnotetext{
${ }^{8}$ Due to increasing real earnings, the share of people with earnings above the cap has increased over time; from about 10 percent in the 1980 s to about 30 percent in the 2000s (Hedborg, 2012).

${ }^{9}$ In the analysis we condition on some annual labour market income. Thus, persons who are full-time unemployed during a whole year are not included.

${ }^{10} \mathrm{In} 2008$ a time limit of one year for the use of sickness benefit was introduced.
} 


\subsection{Parental benefit and temporary parental benefits}

Parents receive parental benefits if they stay at home for child-care instead of working on the labour market. ${ }^{11}$ Parental benefits are payable for 450 days for each child. One parent may give up the right to parental benefit to the other parent, with the exception of 60 days. Parents with children under 8 years old age are also entitled to unpaid job-protected leave with a great portion of flexibility. During the child's first 18 months both parents can stay at home on a full-time basis with job-protection. Thereafter, parents are allowed to reduce their working hours up to 25 percent until the child turns 8 years old (SFS 1995:584).

In addition to parental benefits, parents are entitled to temporary parental benefits if they have to stay at home to care for an ill child under the age of $12 .{ }^{12}$ Parents are together eligible for temporary parental benefits for 60 days per child and year. After these 60 days, a further sixty days can be taken, if the need for these extra days has been approved by the SIA.

Work absence due to child illness is financially more beneficial than work absence due to own illness since it is compensated for the first day of work absence. Until recently, there was no formal monitoring of absence due to child care. Engström et al. (2007) show that this disharmony between the two insurances leads to a large excess use of temporary benefits and Persson (2011) finds that this also leads to unintended flows from sickness insurance benefits to temporary parental benefits. ${ }^{13}$ Thus, if anything, days on sickness benefits are an underreported measure of work absence. ${ }^{14}$

\footnotetext{
${ }^{11}$ This holds also for persons without earnings who receive a flat rate of 60 SEK (approx. 6 Euro) per day.

${ }^{12}$ This also applies if the person who normally looks after the child falls ill.

${ }^{13}$ The first report started a lively debate in Sweden about cheating parents, and no the 1st of July 2008 the rules were changed. As a result, until recently, the day-care centre had to confirm - via a special certificate - that the child has been absent before the SIA pays out temporary parental benefit.

${ }^{14}$ This study focuses on sickness absence longer than 14 days. Thus, the extent of flows from sickness benefits to the temporary parental benefits should be small.
} 


\section{Empirical strategy, data, descriptive statis- tics, and graphical evidence}

\subsection{The empirical strategy}

There are several challenges associated with estimating the effect of parenthood on work absence due to own sickness. First, it is reasonable to believe that the likelihood of having a child, as well as the timing of when a couple decides to have a child, is correlated with health and labour market success. Second, the spouses probably affect each other. To this end, we restrict the analysis to the estimation of an effect of parenthood on the gender difference in sickness absence for those becoming parents.

By asking how the within-couple gender gap changes when a couple enters parenthood, we control for a lot of unobserved individual characteristics that might be correlated with parenthood. In order to be clear on the identification strategy, it is formalized in Appendix A. The take-home message from Appendix A is that we are able to identify the effect of parenthood on the gender gap in sickness absence under the assumption that the expected potential gender gap in sickness absence in the absence of a child is constant for our population.

The following discussion will hopefully make the identification assumption palatable. Both groups (men and women) are affected by the intervention (entering parenthood), but we allow the magnitude of the effect to differ between the genders. The identifying assumption is the same as in a traditional difference-in-differences setting, i.e., the intervention must be strictly exogenous. That is, the timing of when to have a child should not be determined by expected shocks to the within-family gender difference in sickness absence the couple would have experienced in absence of entering parenthood. This means that the timing of entering parenthood should not be influenced by, for us, unobservable information about sickness absence changes of men in comparison to women or vice versa.

Although we find no differences in sickness absence before entering parenthood, there are several reasons to believe that also men and women without children would differ in their sickness absence behaviour. Women have, for instance, lower average earnings. Since there is a cap in the in- 
surance this means that, on average, women face higher real replacement rates than men. Another potential reason for different take up rates among men and women can be the highly gender segregated Swedish labour market (see, e.g., SOU, 2004). However, in general, the work environment for the males is worse than the work environment for the females (see e.g. Broström et al., 2004, Angelov et al., 2011 and Mastekaasa and Olsen, 2000), which suggests a gender gap in the opposite direction than the one we observe in data. By using the pre-birth within-household differences we control for potential differences due to a gender segregated labour market. Another caveat is that the gender segregated labour market might imply gender differential business cycle effects, which are important to control for. That is why we estimate the effect by ordinary least squares (OLS), which allows us to control for business cycle effects. We also control for a restricted set of potential confounders that may affect the timing of parenthood and difference in take up rates of sickness benefits. To this end, we control for differences in education, income and age.

Below, we specify the regression model used in estimation. The structure of our data implies that there are two time dimensions; time since birth and calender time. This is because we pool panel data for couples that get their first child in different years. Let $c=1986,1987, \ldots, 2008$ index calendar time. Time since birth can be measured in months (the frequency we use for sickness absence and in-hospitalization) or years (the frequency of our income and education level data). Thus, let $t=-155,-154, \ldots, 203$ denote month since birth, where $t=0$ is the birth month. Moreover, let $j=-12,-11, \ldots, 17$ denote time since birth measured in years. This index is defined such that $j=0$ during the 12 -month period in which the last month is the month of birth. Thus, $j=1$ during the first child's first year, $j=2$ during the first child's second year, etc. Using the index definitions above, we estimate the following regression model for a couple, where we have suppressed the couple index for simplicity:

$$
\begin{aligned}
\widetilde{s}_{c t j} & =\alpha_{\text {pre }}+\alpha_{\text {preg }} \mathbf{1}(-9 \leq t \leq 0)+\sum_{s=1}^{17} \alpha_{s} \mathbf{1}(s=j) \\
& +\widetilde{\boldsymbol{x}}_{j}^{\prime} \boldsymbol{\phi}_{1} \mathbf{1}(j<-2)+\widetilde{\boldsymbol{x}}_{-2}^{\prime} \boldsymbol{\phi}_{2} \mathbf{1}(j \geq-2)+\theta_{c}+u_{c t j},
\end{aligned}
$$


where $\widetilde{s}_{c t j}=s_{f c t j}-s_{m c t j}$ is the $(f)$ emale- $(m)$ ale gap in sickness absence, $\mathbf{1}($.$) is the indicator function which takes the value one when the expression$ within the parenthesis is true and zero otherwise, $\widetilde{\boldsymbol{x}}_{j}=\left(\boldsymbol{x}_{f j}-\boldsymbol{x}_{m j}\right)$ is a covariate vector of gender differences during year $j$ before/after birth, and $L$ is the maximum labour market history before birth (155 months). We control for calendar time by including year dummies $\theta_{c}$ in the model, with the normalization $\theta_{1986}=0$. Note that $\boldsymbol{x}_{q j}$ for $q=f$ and $m$, is measured at yearly frequency and that for observations after $j=-3$, we measure the control variables at their pre-pregnancy levels at $j=-2 .{ }^{15}$ Our main parameters of interest are $\alpha_{s}$ for $s=1,2, \ldots, 17$, which measure the effect of parenthood on the female-male sickness absence gap during the child's sth year since birth.

The intercept parameter $\alpha_{\text {pre }}$ controls for pre-pregnancy differences in sickness absence levels. To get identification, it is enough to have one observation of the pre-child gender difference in sickness absence (see (5) in the appendix). By using all available pre-child observations to estimate $\alpha_{\text {pre }}$ in (1), we achieve better precision. The pregnancy parameter $\alpha_{\text {preg }}$ takes into account the sharp increase in the relative sickness absence during pregnancy which can be observed in figure 5. As we observe women and men for a maximum of 203 months after parenthood we are in a position of estimating 203 ex post birth parameters. However, as we believe is clear from the analysis provided below, we do not lose any information by keeping the analysis at the yearly level.

\subsection{Data}

The data are taken from universal administrative registers from various sources covering all residents in Sweden. First, using the so called multigeneration register, we define the population by parents who received their first born child between 1992 and 1998. We can link parents to their biological children and have information on birth year and month as well as birth order. For this population, we have also information taken from LOUISE, which is an administrative register covering all residents in Sweden aged between 16 and 65, updated on an yearly basis. From this register we have

\footnotetext{
${ }^{15}$ This matters only for income and education, as the age difference is time invariant.
} 
information about sex, age, pre-child labour market income and pre-child education.

The observation units are matched couples, i.e., men and women who got their first-born child together. To all couples, we have added individual information on the use of sickness benefits from SIA and in-hospital care data from the National Board of Health and Welfare. This information also stems from national registers covering the whole population. Data on sickness absence and in-hospitalization contains information on both start and end date of a spell on sickness benefits and in-hospital care. This information we have summed up on a monthly basis separately for each spouse.

The data coverage for sickness absence implies that we can follow each couple at least 6 years before and at least 10 years after the arrival of the first child. Parents who received their first child in 1992 are followed for as much as 16 years after the arrival of the first child, while parents whose first child was born in 1998 are followed 12 years before the arrival of the first child. Table 1 summarizes the period of coverage of our sickness data, measured in years. ${ }^{16}$

The panel structure allows us to study the dynamics of the withincouple difference in sickness absence over the years before and after the arrival of the first child. That is, we are able to draw conclusions about both short- and long-term effects of entering parenthood. In principle, to obtain such variation in our data, it would be enough to follow parents who had their first child in a certain year (say, 1995). By estimating the dynamics of several parent cohorts, we obtain an average effect of having

Table 1: Data coverage for parents receiving their first child in different years

\begin{tabular}{lccc}
\hline \hline Year of birth, first child & 1992 & 1995 & 1998 \\
\hline Data coverage, years before birth of first child & 6 & 9 & 12 \\
Data coverage, years after birth of first child & 16 & 13 & 10 \\
\hline \hline
\end{tabular}

Notes: In the analysis, we use data for parents giving first birth in 1992-1998. Intermediate years not shown here in order to save space.

\footnotetext{
${ }^{16}$ The coverage period for in-hospitalization data is somewhat shorter, from 1987 to 2005.
} 
a child on the gender difference in sickness absence, based on parents who had their first child in different time points of the business cycle.

The population is restricted to individuals who are employed before entering parenthood. Strictly speaking, we require a positive income from labour market work two years before entering parenthood for being included in the study population. This restriction is motivated by the fact that sickness benefits are mainly employment based. Thus, of interest are those couples in which both spouses are on the labour market and are eligible for sickness benefits. In conditioning on pre-child labour market attachment, we also make sure that an observation with zero pre-child sickness absence implies no absence due to sickness, and not that the individual lacks eligibility for sickness insurance due non participation in the labour force. In Section 5.2 we perform several robustness tests by varying the degree of required labour market attachment when estimating the effect of parenthood.

\subsection{Descriptive statistics}

Table 2 below presents the data used in the main analysis. This table shows that the mean age when entering parenthood is 27.4 among women and

Table 2: Descriptive statistics

\begin{tabular}{l|cc}
\hline \hline & Mean & Std. dev. \\
\hline Mothers: & & \\
Age at $t=0$ & 27.4 & 4.4 \\
Income at $t=-24$ & 152,023 & 80,386 \\
Education at $t=-24$ & 12.2 & 2 \\
Fathers: & & \\
Age at $t=0$ & 29.6 & 4.9 \\
Income at $t=-24$ & 200,066 & 106,074 \\
Education at $t=-24$ & 12 & 2.1 \\
Female-male gap: & & \\
Age at $t=0$ & -2.2 & 3.7 \\
Income at $t=-24$ & $-48,043$ & 108,404 \\
Education at $t=-24$ & 0.1 & 2.1 \\
\hline
\end{tabular}

Notes: The first child is born in month $t=0$. Income and wages are measured in SEK in 2008 prices. The December 2008 exchange rate was approximately 11 SEK for one Euro. 
29.6 among men. The mean annual labour market income is lower among women than among men two years before entering parenthood; women's average income is 76 percent of men's. This is in a way expected due to the age gap before entering parenthood. The education gap is in the other direction; Swedish women today spend slightly more years in education.

\subsection{Graphical evidence}

In order to illustrate the main finding of this study and to get a first look at data, we present the within-couple gender gap in sickness absence before and after the arrival of the first child in Figure 5. This analysis is done on matched couples (one match is two parents who got their first child together). Using monthly sickness-absence data, we can follow some parents for as long as 155 months before their first child is born (January 1986 to December 1998 for children born in December 1998) and another fraction for 203 months after (January 1992 to December 2008 for children born in January, 1992). The data plotted in Figure 5 represent raw monthly average sickness absence for matched couples who received their first child during the period 1992 to 1998. The spike in female sickness absence occurs before the birth of the first child. This increase in absence is due to problems during pregnancy. During the period directly after child birth, we observe a dramatic decrease in sickness absence for women and during this period mothers are even less absent than fathers. This is most likely because most mothers take use of the paid maternity leave during the child's first year. The main message of this study is however summarized by the difference in evolution of sickness absence occurring two years after the birth of the first child. The gender gap in sickness absence is large and persistent for as long as we can follow the couples.

It should be noted that besides the visible variation of the gender gap in sickness absence over time since birth (on the x-axis), Figure 5 also contains some variation over calendar time (cf. Figure 1). In the empirical analysis that follows, we are able to control for this calendar-year variation, since we use parents who received their first child in various years. This is an important aspect of our data, which allows us to identify the effect of parenthood on the gender gap in sickness absence separately from calendar-year varia- 
tion. For instance, using data for couples who received their first child in one particular year, the effect could be confounded with different labour market shocks or diseases that affect women and men differently. Although if it is very unlikely that the confounders are perfectly correlated with the short-run dynamics of the effect of parenthood (i.e., the pre-birth spike and the decrease during the first year Figure 5), the long-term effect estimates might be contaminated by calendar time shocks, if we only use couples who received their first child during a specific year. Another possible drawback of using parents from one particular year would be the external validity of our results. Thus, by using parents who received their first child in different years, we are able to control for potential confounders, and in addition, our results gain external validity.

\section{Results}

In this section we present results from estimated regression models based on our sample of matched couples. All results are estimated using OLS. Standard errors are estimated by clustering at the couple level. We start by presenting the main results and then we perform several sensitivity analyses.

\subsection{Main results}

We estimate the mean gender gap before pregnancy, i.e., for observations measured at least 10 months before the first child is born; during the 9 months of pregnancy; and during the consecutive years after birth (see equation 1). Table 3 presents estimation results from three different specifications. The first column presents estimates without any controls. In the second column, we add controls for calendar years, and in the third column, we also include controls for the age difference within each couple as well as pre-child differences in income and years of education. All controls are measured at the latest two years before the birth of the first child. All three specifications in Table 3 tell the same story and all estimates are significant at the one percent level; in the long run, the female-male gender gap in sickness absence increased due to parenthood. Before explaining the 


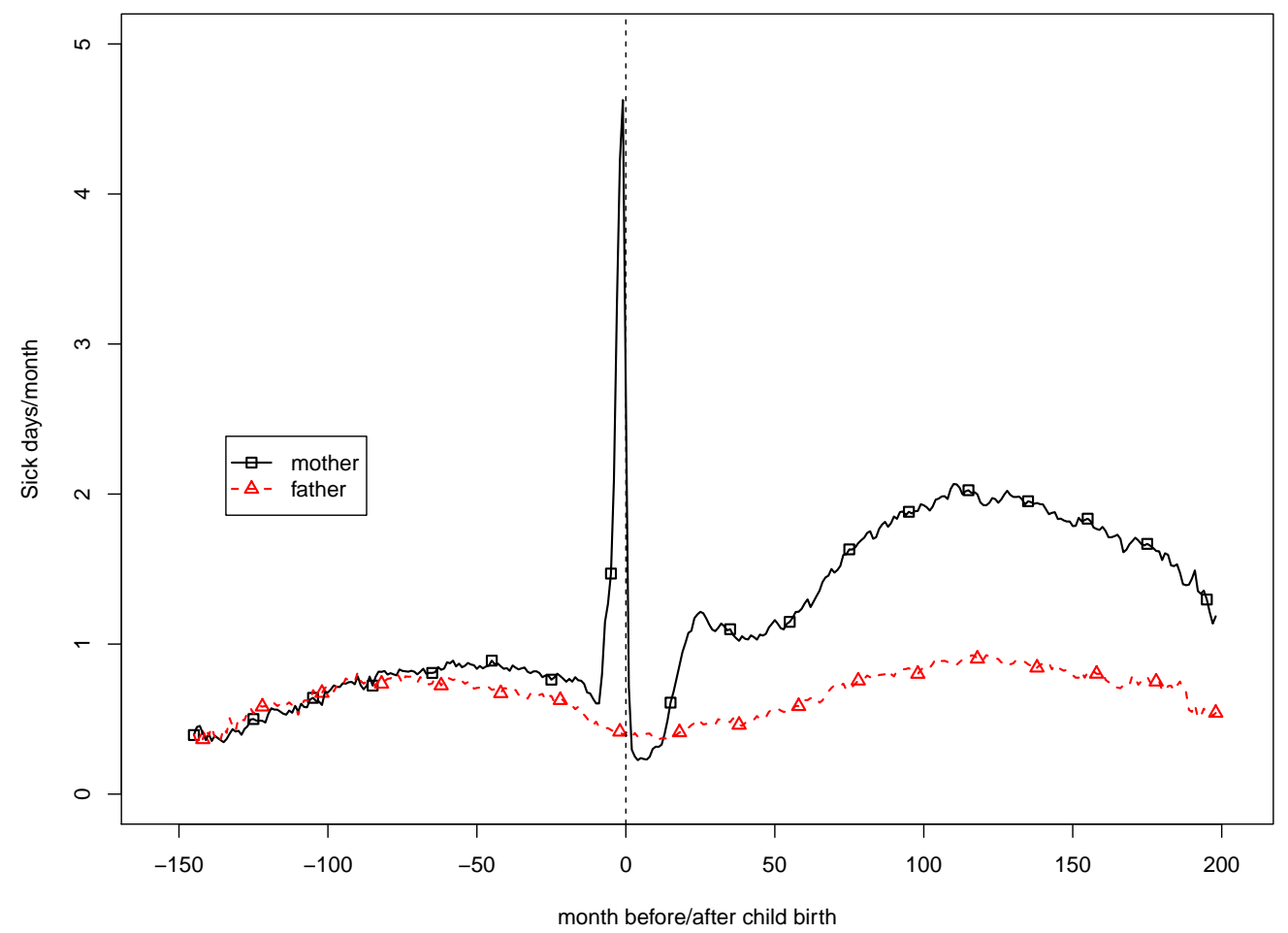

Figure 5: Average days of sickness absence per month before and after the arrival of the first child for mothers and fathers who got their first child at $t=0$.

Note: The analysis is based on all Swedish residents who had their first child between 1992 and 1998, and were active on the labour market two years prior to child birth. Sickness absence data covers the period between 1986 and 2008.

interpretation of each regression coefficient, we discuss how the different model specifications affect the long-term estimate of the gender gap in sickness absence.

As already noted, there has been a substantial variation in the overall gender gap in sickness absence during our study period (see Figure 1). Including calendar year controls reduces the magnitude of the estimated effects for years 3 through 13 since the birth of the first child and leaves the rest of the estimates virtually unchanged. Adding age and pre-child controls does not change the results, except for the intercept term which captures the mean difference before pregnancy. In the model with calendar year controls only, the intercept is negative and not statistically significant. 
In the third column when control variables are added, the intercept is marginally positive (0.04 days more per month) and statistically significant at the 5 percent level. All in all, we believe this provides some evidence of similar trends in sickness absence before entering parenthood, once we have controlled for calendar year effects.

In the following we discuss the estimates in the third column (qualitatively we have the same results in the second column however). The results confirm what was already seen from the graphical analysis displayed in Figure 5. Pregnancy increases the gender gap in sickness absence drastically: the effect is 1.7 days per month during this period. This increase is arguably due to mothers' pregnancy-related illnesses. During the first year after birth, the difference is instead negative, i.e., fathers are on average more absent due to sickness than mothers: -0.16 days per month. This is most likely because most mothers are on paid maternity leave during the child's first year. During this period of maternity leave there is in general no need to take use of the sickness insurance in order to be absent from work for health reasons. ${ }^{17}$

During the second year, the gender gap in sickness absence increases by 0.32 days per month, which is a substantial increase. This result is to some extent driven by a high frequency of siblings being born about two years after the first child birth. We discuss the implications of subsequent births in the next section. Finally, our main parameters of interest are the long-term effects from year 3 onwards. The estimates range from 0.28 (year 5) to 0.88 days per month (year 16), which corresponds to the shift in the sickness absence gap in Figure 4, but here estimated with the full set of controls including calendar-year categorical variables. There seems to be gradual increases in the effect of pregnancy approximately between year 5 and 14 , and no change further away from birth.

\footnotetext{
${ }^{17}$ Note, however, that sickness benefit could be paid out during the parental leave if, for example, the illness prohibits the mother from taking care of the child.
} 
Table 3: Baseline specification with yearly effects.

\begin{tabular}{|c|c|c|c|}
\hline & No controls & Calender year & Full set of controls \\
\hline \multirow[t]{2}{*}{ intercept } & $0.0917^{* * *}$ & -0.0186 & $0.0426^{*}$ \\
\hline & $(0.0138)$ & $(0.0184)$ & $(0.0204)$ \\
\hline \multirow[t]{2}{*}{ pregnancy } & $1.698^{* * *}$ & $1.709^{* * *}$ & $1.701^{* * *}$ \\
\hline & $(0.0339)$ & $(0.0370)$ & $(0.0371)$ \\
\hline \multirow[t]{2}{*}{ year 1} & $-0.169^{* * *}$ & $-0.156^{* * *}$ & $-0.162^{* * *}$ \\
\hline & $(0.0226)$ & $(0.0322)$ & $(0.0322)$ \\
\hline \multirow[t]{2}{*}{ year 2} & $0.345^{* * *}$ & $0.326^{* * *}$ & $0.323^{* * *}$ \\
\hline & $(0.0283)$ & $(0.0399)$ & $(0.0399)$ \\
\hline \multirow[t]{2}{*}{ year 3} & $0.564^{* * *}$ & $0.493^{* * *}$ & $0.493^{* * *}$ \\
\hline & $(0.0331)$ & $(0.0466)$ & $(0.0464)$ \\
\hline \multirow[t]{2}{*}{ year 4} & $0.469^{* * *}$ & $0.335^{* * *}$ & $0.337^{* * *}$ \\
\hline & $(0.0333)$ & $(0.0514)$ & $(0.0513)$ \\
\hline \multirow[t]{2}{*}{ year 5} & $0.501^{* * *}$ & $0.277^{* * *}$ & $0.281^{* * *}$ \\
\hline & $(0.0367)$ & $(0.0586)$ & $(0.0584)$ \\
\hline \multirow[t]{2}{*}{ year 6} & $0.640^{* * *}$ & $0.321^{* * *}$ & $0.327^{* * *}$ \\
\hline & $(0.0413)$ & $(0.0691)$ & $(0.0689)$ \\
\hline \multirow[t]{2}{*}{ year 7} & $0.839^{* * *}$ & $0.445^{* * *}$ & $0.452^{* * *}$ \\
\hline & $(0.0466)$ & $(0.0814)$ & $(0.0811)$ \\
\hline \multirow[t]{2}{*}{ year 8} & $0.934^{* * *}$ & $0.492^{* * *}$ & $0.501^{* * *}$ \\
\hline & $(0.0493)$ & $(0.0940)$ & $(0.0936)$ \\
\hline \multirow[t]{2}{*}{ year 9} & $0.984^{* * *}$ & $0.533^{* * *}$ & $0.543^{* * *}$ \\
\hline & $(0.0517)$ & $(0.108)$ & $(0.107)$ \\
\hline \multirow[t]{2}{*}{ year 10} & $1.031^{* * *}$ & $0.627^{* * *}$ & $0.640^{* * *}$ \\
\hline & $(0.0535)$ & $(0.122)$ & $(0.121)$ \\
\hline \multirow[t]{2}{*}{ year 11} & $0.976^{* * *}$ & $0.640^{* * *}$ & $0.655^{* * *}$ \\
\hline & $(0.0546)$ & $(0.132)$ & $(0.131)$ \\
\hline \multirow[t]{2}{*}{ year 12} & $0.975^{* * *}$ & $0.709^{* * *}$ & $0.727^{* * *}$ \\
\hline & $(0.0583)$ & $(0.142)$ & $(0.142)$ \\
\hline \multirow[t]{2}{*}{ year 13} & $0.922^{* * *}$ & $0.747^{* * *}$ & $0.765^{* * *}$ \\
\hline & $(0.0626)$ & $(0.152)$ & $(0.151)$ \\
\hline
\end{tabular}

Continued on Next Page... 
Table 3 - Continued

\begin{tabular}{l|ccc}
\hline \hline & No controls & Calender year & Full set of controls \\
\hline \multirow{2}{*}{ year 14 } & $0.883^{* * *}$ & $0.801^{* * *}$ & $0.819^{* * *}$ \\
& $(0.0673)$ & $(0.161)$ & $(0.160)$ \\
year 15 & $0.815^{* * *}$ & $0.836^{* * *}$ & $0.854^{* * *}$ \\
year 16 & $(0.0748)$ & $(0.171)$ & $(0.171)$ \\
& $0.726^{* * *}$ & $0.860^{* * *}$ & $0.882^{* * *}$ \\
year 17 & $(0.0871)$ & $(0.184)$ & $(0.183)$ \\
calendar year controls & $0.603^{* * *}$ & $0.830^{* * *}$ & $0.852^{* * *}$ \\
age and pre-child controls & $(0.120)$ & $(0.207)$ & $(0.206)$ \\
$N$ & no & yes & yes \\
$R^{2}$ & $5,017,248$ & $5,017,248$ & yes \\
adj. $R^{2}$ & 0.005 & 0.006 & $0.017,248$ \\
\hline \hline
\end{tabular}

Notes: Standard errors are reported in parentheses and clustered at couple level. Significance levels are denoted by ${ }^{*}(\mathrm{p}<0.05),{ }^{* *} p<0.01$, and ${ }^{* * *} p<0.001$. The complete set of controls consists of calender year dummies, age difference, and pre-child controls for differences in income and education.

\subsection{Sensitivity analysis}

In this section we address two concerns: subsequent births and the composition of individuals eligible for sickness benefit. The pregnancy itself and the days around the birth are associated with a sharp increase in the sickness absence gap. Thus, the shift in the sickness absence after the birth of the first child could potentially be explained by subsequent births and short-term pregnancy-related illnesses. On the other hand, the estimated effect during year 1 is negative, suggesting a short-term negative effect of giving birth. Moreover, although we condition on being eligible for sickness benefit before entering parenthood, parenthood could cause women to leave the labour force. If anything, this would attenuate the estimated effect toward zero. To investigate these issues, we present several sensitivity 
analyses below.

\subsubsection{Subsequent births}

We start by investigating how a second child affects the gender gap in sickness absence. In this analysis, the first-child dummy captures sickness absence differences only as long as the mother is not pregnant with her second child. As soon as the second pregnancy begins (i.e., 9 months before the birth of the second child), the second-child pregnancy dummy captures the sickness absence difference. The first column in Table 4 presents the results from this analysis. The first-child estimates now capture the dynamics of the gender gap in sickness absence for a) the minority of couples that only get one child during the period, and b) the period after the birth of the first child and before the birth of the second child among the majority of couples who get a second child. In contrast, the variation used to estimate the second-child parameter stems solely from couples that get a second child.

The long-term effects (for year 3 since the birth of the first child and thereafter) are estimated using a dummy variable that has the value one if a) more than two years have passed since the birth of the first child, and b) for couples that get a second child, either more than two years have passed since the second birth, or the mother is not yet pregnant with the second child. ${ }^{18}$

A comparison of the first- and second-child estimates in the first column of Table 4 suggests that the positive pregnancy effect is somewhat higher for the second than for the first child (2.07 compared to 1.69 sick-days/month). The negative first-year effect is about twice as large in absolute terms for the second child compared to the first child ( -0.39 and -0.20 , respectively), but the second-year effects are both positive and have about the same magnitude.

\footnotetext{
${ }^{18}$ An example might be useful. Assume that couple A get their first child in June 1996, and no children thereafter. The long-term effect for year 4 is captured by a dummy variable valued one for monthly sick-absence observations that occur during the period June 1999 to May 2000. Assume furthermore that another couple (B) get their first child in June 1996 and a second child in June 1999. Then no variation from couple B is used in the estimation of the effect for year 4. Instead, the sickness absence observations for couple B during the period June 1999 to May 2000 are used in the estimation of the effect for year 1 (2nd child).
} 
Table 4: Robustness checks

\begin{tabular}{|c|c|c|c|c|c|}
\hline & (1) & $(2)$ & $(3)$ & (4) & $(5)$ \\
\hline \multirow[t]{2}{*}{ intercept } & $0.0422^{*}$ & 0.0361 & 0.0399 & $0.130^{* * *}$ & $0.0490^{*}$ \\
\hline & $(0.0204)$ & $(0.0211)$ & $(0.0219)$ & $(0.0309)$ & $(0.0235)$ \\
\hline \multirow[t]{2}{*}{ pregnancy (1st child) } & $1.686^{* * *}$ & $1.703^{* * *}$ & $1.746^{* * *}$ & $1.489^{* * *}$ & $1.735^{* * *}$ \\
\hline & $(0.0363)$ & $(0.0358)$ & $(0.0397)$ & $(0.0348)$ & $(0.0412)$ \\
\hline \multirow[t]{2}{*}{ year 1 (1st child) } & $-0.197^{* * *}$ & $-0.144^{* * *}$ & $-0.174^{* * *}$ & $-0.0591^{*}$ & $-0.211^{* * *}$ \\
\hline & $(0.0297)$ & $(0.0276)$ & $(0.0310)$ & $(0.0280)$ & $(0.0339)$ \\
\hline \multirow[t]{2}{*}{ year 2 (1st child) } & $-0.0875^{*}$ & -0.0356 & $-0.0939^{*}$ & -0.0626 & -0.0730 \\
\hline & $(0.0382)$ & $(0.0355)$ & $(0.0407)$ & $(0.0341)$ & $(0.0429)$ \\
\hline \multirow[t]{2}{*}{ pregnancy (2nd child) } & $2.072^{* * *}$ & $2.187^{* * *}$ & $2.063^{* * *}$ & $2.003^{* * *}$ & $2.047^{* * *}$ \\
\hline & $(0.0500)$ & $(0.0501)$ & $(0.0534)$ & $(0.0514)$ & $(0.0579)$ \\
\hline \multirow[t]{2}{*}{ year 1 (2nd child) } & $-0.389^{* * *}$ & $-0.307^{* * *}$ & $-0.346^{* * *}$ & $-0.269^{* * *}$ & $-0.408^{* * *}$ \\
\hline & $(0.0443)$ & $(0.0418)$ & $(0.0455)$ & $(0.0414)$ & $(0.0512)$ \\
\hline \multirow[t]{2}{*}{ year 2 (2nd child $)$} & $-0.105^{*}$ & -0.0809 & $-0.115^{*}$ & $-0.115^{* *}$ & $-0.146^{*}$ \\
\hline & $(0.0521)$ & $(0.0477)$ & $(0.0540)$ & $(0.0420)$ & $(0.0603)$ \\
\hline \multirow[t]{2}{*}{ year 3} & $0.219^{*}$ & $0.281^{* *}$ & $0.283^{* *}$ & 0.161 & $0.240^{*}$ \\
\hline & $(0.0958)$ & $(0.0951)$ & $(0.107)$ & $(0.0874)$ & $(0.0980)$ \\
\hline \multirow[t]{2}{*}{ year 4} & $0.334^{* * *}$ & $0.409^{* * *}$ & $0.338^{* * *}$ & $0.233^{* *}$ & $0.356^{* * *}$ \\
\hline & $(0.0882)$ & $(0.0851)$ & $(0.0968)$ & $(0.0738)$ & $(0.0958)$ \\
\hline \multirow[t]{2}{*}{ year 5} & $0.259^{* * *}$ & $0.280^{* * *}$ & $0.256^{* * *}$ & $0.193^{* * *}$ & $0.297^{* * *}$ \\
\hline & $(0.0664)$ & $(0.0620)$ & $(0.0709)$ & $(0.0549)$ & $(0.0773)$ \\
\hline \multirow[t]{2}{*}{ year 6} & $0.283^{* * *}$ & $0.301^{* * *}$ & $0.259^{* * *}$ & $0.133^{*}$ & $0.339^{* * *}$ \\
\hline & $(0.0689)$ & $(0.0637)$ & $(0.0731)$ & $(0.0552)$ & $(0.0798)$ \\
\hline \multirow[t]{2}{*}{ year 7} & $0.366^{* * *}$ & $0.386^{* * *}$ & $0.306^{* * *}$ & $0.239^{* * *}$ & $0.415^{* * *}$ \\
\hline & $(0.0770)$ & $(0.0705)$ & $(0.0813)$ & $(0.0606)$ & $(0.0883)$ \\
\hline \multirow[t]{2}{*}{ year 8} & $0.405^{* * *}$ & $0.419^{* * *}$ & $0.337^{* * *}$ & $0.249^{* * *}$ & $0.518^{* * *}$ \\
\hline & $(0.0865)$ & $(0.0793)$ & $(0.0925)$ & $(0.0670)$ & $(0.0993)$ \\
\hline \multirow[t]{2}{*}{ year 9} & $0.437^{* * *}$ & $0.438^{* * *}$ & $0.392^{* * *}$ & $0.202^{* *}$ & $0.555^{* * *}$ \\
\hline & $(0.0985)$ & $(0.0907)$ & $(0.105)$ & $(0.0755)$ & $(0.113)$ \\
\hline \multirow[t]{2}{*}{ year 10} & $0.529^{* * *}$ & $0.548^{* * *}$ & $0.525^{* * *}$ & $0.315^{* * *}$ & $0.651^{* * *}$ \\
\hline & $(0.111)$ & $(0.103)$ & $(0.119)$ & $(0.0855)$ & $(0.127)$ \\
\hline
\end{tabular}

Continued on Next Page... 
Table 4 - Continued

\begin{tabular}{l|ccccc}
\hline \hline & $(1)$ & $(2)$ & $(3)$ & $(4)$ & $(5)$ \\
\hline \multirow{2}{*}{ year 11 } & $0.549^{* * *}$ & $0.574^{* * *}$ & $0.582^{* * *}$ & $0.325^{* * *}$ & $0.665^{* * *}$ \\
& $(0.121)$ & $(0.113)$ & $(0.130)$ & $(0.0934)$ & $(0.138)$ \\
year 12 & $0.619^{* * *}$ & $0.603^{* * *}$ & $0.654^{* * *}$ & $0.355^{* * *}$ & $0.768^{* * *}$ \\
year 13 & $(0.131)$ & $(0.122)$ & $(0.141)$ & $(0.101)$ & $(0.149)$ \\
year 14 & $0.650^{* * *}$ & $0.630^{* * *}$ & $0.662^{* * *}$ & $0.387^{* * *}$ & $0.812^{* * *}$ \\
year 15 & $(0.141)$ & $(0.131)$ & $(0.152)$ & $(0.109)$ & $(0.161)$ \\
year 16 & $0.706^{* * *}$ & $0.729^{* * *}$ & $0.720^{* * *}$ & $0.491^{* * *}$ & $0.863^{* * *}$ \\
& $(0.150)$ & $(0.141)$ & $(0.162)$ & $(0.117)$ & $(0.172)$ \\
year 17 & $0.739^{* * *}$ & $0.793^{* * *}$ & $0.796^{* * *}$ & $0.539^{* * *}$ & $0.924^{* * *}$ \\
& $(0.161)$ & $(0.151)$ & $(0.173)$ & $(0.127)$ & $(0.185)$ \\
\hline$N$ & $0.769^{* * *}$ & $0.810^{* * *}$ & $0.820^{* * *}$ & $0.574^{* * *}$ & $1.023^{* * *}$ \\
$R^{2}$ & $(0.174)$ & $(0.163)$ & $(0.186)$ & $(0.139)$ & $(0.200)$ \\
adj. $R^{2}$ & $0.739^{* * *}$ & $0.849^{* * *}$ & $0.813^{* * *}$ & $0.616^{* * *}$ & $0.948^{* * *}$ \\
\hline \hline
\end{tabular}

Notes: Standard errors are reported in parentheses and clustered at couple level. Significance levels are denoted by ${ }^{*}(\mathrm{p}<0.05),{ }^{* *}(\mathrm{p}<0.01)$, and ${ }^{* * *}(\mathrm{p}<0.001)$. All specifications include calender year controls, age difference, and pre-child controls for differences in income and education.

(1) Baseline with second child effects, (2) Mothers' and fathers' income > 0, (3) Mothers' and fathers' pre-child income > 50,000 SEK, (4) Mothers' and fathers' income > 50,000 SEK, and (5) Couples with at most two children

Finally and most importantly, the long-term yearly effects of parenthood are of the same magnitude whether we control for second-child pregnancy and second-child year 1 and 2 effects (first column of Table 4), or not (third column of Table 3). To further push this point, we have estimated the specification with second-child controls for the sub-sample of couples that get at most two children (fifth column of Table 4). The results are qualitatively unchanged, but the long-term estimates are even somewhat 
higher for this group. This is an important result as it implies that the long-term results of parenthood that we estimate are not driven by later pregnancies.

\subsubsection{Composition of sickness benefit eligible individuals}

In order to investigate whether a potential change in the composition of individuals eligible for sickness benefit after entering parenthood may affect the results, we have re-estimated the model on a sample in which we require a positive income also after the arrival of the first child. The estimated effects are virtually the same with and without this additional restriction (see columns 1 and 2 in Table 4), undoubtedly due to the fact that most individuals in Sweden stay in the labour force also after they have entered parenthood. Furthermore, making the pre-child labour market attachment condition more restrictive than in the baseline sample (incomes greater than 50,000 SEK, or approximately 4,500 EUR, two years before child birth $)^{19}$, implies a loss of about one million observations, but no significant change in the results (see column 3 in Table 4). Finally, when we make the restriction even harder so that the incomes of both parents must be above 50,000 SEK both before and after child birth, the long-term effects are smaller (see column 4 in Table 4), but the effect for year 15 is still as much as 0.54 sick days/month.

\section{Family responsibilities and sickness absence}

In this section we discuss and investigate possible explanations for the gender differences in sickness absence usage after parenthood observed in the previous section. We have two ideas. The first focuses on women's dual responsibility associated with parenthood, which may cause either a relative deterioration in female health (cf. Bratberg et al., 2002) or an improvement in health (cf. Paringer, 1983). The second concerns changes in economic incentives within the household. We first discuss these ideas and then present the empirical results.

\footnotetext{
${ }^{19}$ The amounts are expressed in year 2008 prices.
} 


\subsection{A gender differential change in health}

Bratberg et al. (2002) claim that the gender gap in sickness absence stems from the psychological pressure of the dual role of women, the so called "double burden". As the average total time spent on working is the same for men and women (SCB, 2009), we believe that this hypothesis should not be interpreted as an effect from a higher work load of the women on average, but rather as a potential effect from psychological strain of switching between roles. ${ }^{20}$ The role strain theory argues that having multiple roles is detrimental for an individual's health and may thus increase sickness absence. $^{21}$ Thus, according to this hypothesis, women's health would deteriorate after entering parenthood.

However, the dual role could also lead to improved health among women. Paringer (1983) suggests that, due to women's dual role, female health is likely to be more important for the household than male health, since female illness does not only include forgone earnings, but also creates an additional cost in terms of lost home production (Paringer, 1983). In this setting, it may be rational for the household to be more precautious in case of a negative female health shock by increasing female work absence more than for a similar male health shock, or in other words: to be more risk averse when it comes to her health then his. According to Paringer's hypothesis, we would observe an increased female-male gap in sickness absence, but a long-term improvement in women's health.

To investigate how well these empirical predictions correspond to empirical outcomes, we apply the same empirical strategy as in the previous analysis, but instead of sickness absence as outcome variable, we directly focus on the effect on health by analysing in-hospital care data.

\footnotetext{
${ }^{20}$ The similarity in total time worked corresponds well with statistics from time use studies in USA, Germany and the Netherlands (Burda et al., 2008).

${ }^{21}$ There is also a large literature theorizing on benefits of multiple roles (the role enhancement theory), as it might make an individual feel that his or her life is more meaningful. This effect would, hence, work in the other direction, namely improving individual health. For more discussion about multiples roles and its implications, see the literature review in, e.g., Mastekaasa et al. (2000).
} 


\subsection{Economic incentives}

It is well known that insurance coverage may change individual behaviour. Due to asymmetric information about employee health, the sickness insurance system (with high replacement rates) can be used as a way of adjusting employees' working time (cf. Allen, 1981 and Johansson and Palme, 1996). Individuals can use sickness absence as a way of increasing their leisure time so that their real wage equals their marginal value of leisure. ${ }^{22}$ The starting point in this paper is that parenthood implies a new inevitable time-consuming task at home. A response to this new home commitment could be to reduce female labour supply as many women do. However, another way of reducing the labour working time is to increase the time on sickness benefits. We denote this potential effect an ex ante moral hazard effect.

In comparison to low-income mothers, high-income mothers have most likely better opportunities to deal with the new commitment at home. They have more opportunities to adjust their contracted labour supply, to buy household goods on the market, and to employ flexible working hours and to telework. Thus, it is reasonable to assume that low-income mothers have stronger incentives to increase their time on sickness benefits than high-income mothers. An informal test of this ex ante moral hazard behaviour is thus given by studying whether the magnitude of the effect of parenthood varies with mothers' pre-birth income level. A negative relationship between pre-birth income and the effect of parenthood on the sickness absence gender gap provides evidence that our main effect is partly driven by ex ante moral hazard among mothers.

Economic theory together with empirical evidence tells us that ex post moral hazard is important in the Swedish sickness insurance system (see e.g. Johansson and Palme, 2005). That is, sickness absence decreases with the cost of being absent. When women reduce their working time after parenthood, the cost of being absent may be reduced. For high-income women there may be a direct effect but there is also, most likely, a more important indirect effect. The direct effect stems from the fact that there is

\footnotetext{
${ }^{22}$ Real wage $=($ income + benefits $) /($ contracted working hours - time on sickness benefits)
} 
a cap in the sickness insurance system. For women with incomes above the cap, the income loss in case of sickness absence is lower than the nominal replacement rate in the insurance. Consequently, a reduction in working time for these women implies an increase in real replacement rates. The indirect effect stems from a change in employers' expectations about worker performance due to the reduction in working time. High presence at work is most likely taken as a signal of aspiration and productivity by most employers. Thus, work absence as measured by sickness absence and/or a reduction of working time due to household work might negatively affect future advancements at the workplace. Less opportunities and possibilities of advancement will most likely affect work incentives, which in turn lower the threshold for using the sickness insurance. Seen from this perspective, the fact that many women reduce their labour supply after entering parenthood means that their cost of being absent falls with their lower labour market attachment.

We investigate the hypothesis of ex post moral hazard behaviour due to a change in female labour market attachment after parenthood by studying whether a higher income increase between year $j=-2$ and year $j=s-1$ is related to a lower effect of parenthood on sickness absence during year $s$. By using lagged income as a measurement of labour supply, we mitigate the obvious measurement problem, namely that there is a mechanical relation between labour income ${ }^{23}$ and the number of days absent due to sickness.

\subsection{Empirical results}

\subsubsection{Health}

In order to investigate whether there is a negative health effect of family formation on the gender gap in health, we use in-hospital care data. As we have hospitalization data for a shorter period of time (1987 to 2005 instead of 1986 to 2008 as is the case of sickness absence), we re-estimate, for the sake of comparison, the effect on sickness absence for this shorter period. A comparison between the results for hospitalization and sickness absence are presented in Table 5. The empirical specification and population is the

\footnotetext{
${ }^{23}$ We measure labour supply as labour income since we lack an appropriate measure on labour supply in terms of hours worked.
} 
same as in column 5 in Table 4 (couples with at most two children), but there are fewer observations because of the shorter period. The results on sickness absence are very similar to the ones presented previously for the longer time period (cf. column 5 in Table 4 and column 2 in Table 5). Furthermore, as expected, there is a substantial increase in in-hospitalization for women during both the first and the second pregnancy ( 0.61 and 0.43 in hospitalization days/month, respectively). However, besides the pregnancy effects, there is no evidence of a long-term increase in the female-male gap in in-hospitalization. In fact, if anything, there is some evidence on the opposite: after the arrival of the first child, the in-hospitalization rate among mothers seems to decrease somewhat relative to the corresponding rate among fathers.

Thus, we find no support for that the woman's health is more negatively affected than the man's after parenthood. It is clear from Table 4 that the effects of parenthood on the gender gap in hospitalization are only related with pregnancy - we find no long-term negative effects. Instead we find a long-term effect in the opposite direction, indicating some support for the theory proposed by Paringer (1983), namely that women - as the main household producers - use work absence as a means of health investment.

Table 5: Hospitalization and sickness absence, couples with at most two children.

\begin{tabular}{l|cc}
\hline \hline & Hospitalization & Sickness absence \\
\hline \multirow{2}{*}{ intercept } & 0.000739 & $0.110^{* * *}$ \\
& $(0.00390)$ & $(0.0292)$ \\
pregnancy (1st child) & $0.609^{* * *}$ & $1.740^{* * *}$ \\
& $(0.00442)$ & $(0.0412)$ \\
year 1 (1st child) & $0.0241^{* * *}$ & $-0.207^{* * *}$ \\
\multirow{3}{*}{ year 2 (1st child) } & $(0.00395)$ & $(0.0340)$ \\
& $-0.0192^{* * *}$ & -0.0688 \\
pregnancy (2nd child) & $(0.00328)$ & $(0.0429)$ \\
& $0.425^{* * *}$ & $2.045^{* * *}$ \\
& $(0.00454)$ & $(0.0580)$ \\
\hline
\end{tabular}

Continued on Next Page... 
Table 5 - Continued

\begin{tabular}{|c|c|c|}
\hline & Hospitalization & Sickness absence \\
\hline \multirow[t]{2}{*}{ year 1 (2nd child) } & -0.00857 & $-0.404^{* * *}$ \\
\hline & $(0.00480)$ & $(0.0510)$ \\
\hline \multirow[t]{2}{*}{ year 2 (2nd child) } & $-0.0225^{* * *}$ & $-0.142^{*}$ \\
\hline & $(0.00387)$ & $(0.0605)$ \\
\hline \multirow[t]{2}{*}{ year 3} & $-0.0191^{*}$ & $0.243^{*}$ \\
\hline & $(0.00957)$ & $(0.0980)$ \\
\hline \multirow{2}{*}{ year 4} & -0.0118 & $0.360^{* * *}$ \\
\hline & $(0.00930)$ & $(0.0958)$ \\
\hline \multirow[t]{2}{*}{ year 5} & $-0.0223^{* * *}$ & $0.301^{* * *}$ \\
\hline & $(0.00581)$ & $(0.0774)$ \\
\hline \multirow[t]{2}{*}{ year 6} & $-0.0143^{*}$ & $0.346^{* * *}$ \\
\hline & $(0.00594)$ & $(0.0799)$ \\
\hline \multirow[t]{2}{*}{ year 7} & $-0.0253^{* * *}$ & $0.428^{* * *}$ \\
\hline & $(0.00652)$ & $(0.0886)$ \\
\hline \multirow[t]{2}{*}{ year 8} & $-0.0253^{* * *}$ & $0.524^{* * *}$ \\
\hline & $(0.00619)$ & $(0.1000)$ \\
\hline \multirow[t]{2}{*}{ year 9} & $-0.0215^{* * *}$ & $0.558^{* * *}$ \\
\hline & $(0.00646)$ & $(0.115)$ \\
\hline \multirow[t]{2}{*}{ year 10} & $-0.0157^{*}$ & $0.647^{* * *}$ \\
\hline & $(0.00725)$ & $(0.132)$ \\
\hline \multirow[t]{2}{*}{ year 11} & $-0.0220^{* *}$ & $0.671^{* * *}$ \\
\hline & $(0.00830)$ & $(0.147)$ \\
\hline \multirow[t]{2}{*}{ year 12} & -0.0136 & $0.878^{* * *}$ \\
\hline & $(0.00740)$ & $(0.165)$ \\
\hline \multirow[t]{2}{*}{ year 13} & -0.00191 & $0.990^{* * *}$ \\
\hline & $(0.00875)$ & $(0.192)$ \\
\hline \multirow[t]{2}{*}{ year 14} & -0.00364 & $0.921^{* * *}$ \\
\hline & $(0.00952)$ & $(0.238)$ \\
\hline$N$ & $3,309,312$ & $3,309,312$ \\
\hline$R^{2}$ & 0.026 & 0.012 \\
\hline
\end{tabular}

Continued on Next Page... 
Table 5 - Continued

\begin{tabular}{l|cc}
\hline \hline & Hospitalization & Sickness absence \\
\hline adj. $R^{2}$ & 0.026 & 0.012 \\
\hline \hline
\end{tabular}

Notes: Standard errors are reported in parentheses and clustered at couple level. Significance levels are denoted by ${ }^{*}(\mathrm{p}<0.05),{ }^{* *}(\mathrm{p}<0.01)$, and ${ }^{* * *}(\mathrm{p}<0.001)$. Both specifications contain calender year dummies, age difference, and pre-child controls for differences in income and education. Estimated for the period 1987-2005, as this is the period of coverage for the in-hospitalization data.

\subsubsection{Economic incentives}

In the following we present heterogeneous effects depending on mothers' pre-birth income and the income trajectory after the arrival of the first child. $^{24}$ The complete results are presented in detail in Table 6 in the Appendix. Here, we present the essence of the results graphically. To keep the discussion simple, we focus on how the effect during the 10th year after the arrival of the first child varies over mothers' pre-birth income as well as their income trajectory. As explained in the Appendix, the signs of the parameter estimates are the same also for other years, and thus by focusing on the effect during year 10 we gain simplicity without losing on generality.

Panel a) in Figure 6 depicts how the effect of parenthood 10 years after the birth of the first child varies with mothers' pre-child income. Taking the estimates from Table 6 in the Appendix at face value, they imply a negative relationship between mothers' pre-child income and the effect of parenthood 10 years after the first child is born. We have chosen the range of the $\mathrm{x}$-axis to represent the range of the empirical distribution of mothers' pre-child income, with almost all the mass between 50,000 and 400,000 SEK measured in 2008 prices (approximately between 4,500 and 36,000 EURO). As the figure shows, although the relationship is negative as expected, the slope is not steep and the relationship implies a positive

\footnotetext{
${ }^{24}$ As the marriage market is characterized by assortative mating in terms of labour market productivity (see, e.g., Boschini et al. 2011) high income fathers may be important. For this reason we have also estimated how the effect varies with the pre-birth income level of the household, which give qualitatively the same results.
} 
effect of parenthood on the gender gap in sickness absence even for very high-income mothers.

Next, to examine the role of mothers' income trajectory, in panel b) in Figure 6, we present how the magnitude of the effect during year 10 varies. The range of the $\mathrm{x}$-axis has been chosen so that it covers most of the empirical distribution of womens' income change between year -2 and 9. As seen from the figure, the effect of parenthood varies significantly with the mothers' income trajectory. For mothers with the highest income trajectories, the effect of parenthood is even negative. In other words, for mothers that have the best labour market attachment, having a child even decreases the female-male gap in sickness absence.

To summarize, mothers' labour market attachment is found to be an important determinant of the effect of parenthood on the gender gap in sickness absence. In contrast, although we find some statistical evidence for the importance of mothers' pre-child income, the latter is not significant in economic terms.

a) Pre-child income

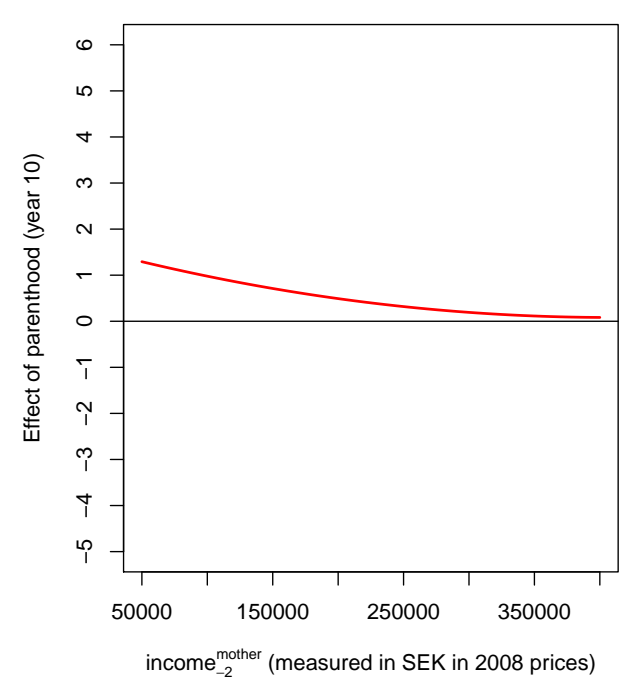

b) Income change

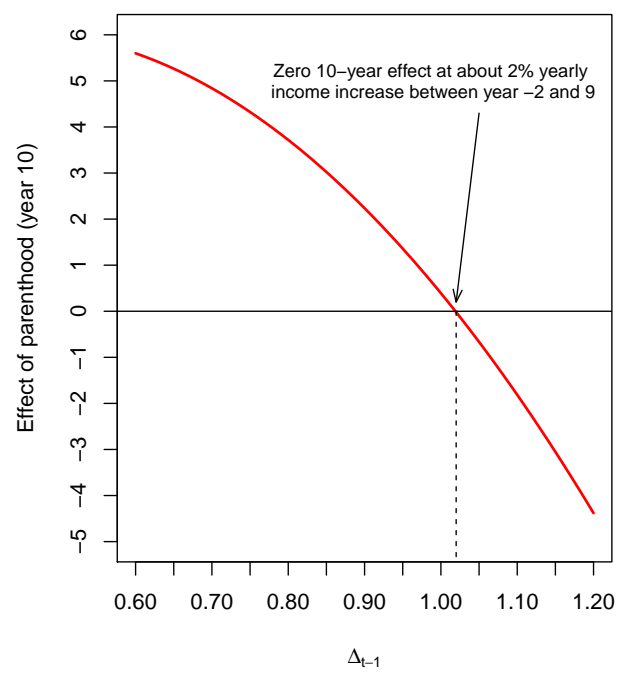

Figure 6: Illustration of how the year 10 effect of parenthood varies with $y_{-2}^{\text {mother }}$ and with $\Delta_{j-1}=\left(y_{j-1}^{\text {mother }} / y_{-2}^{\text {mother }}\right)^{\frac{1}{j+1}}$, where $y_{j}^{\text {mother }}$ is mothers' yearly income $j$ years since birth. See Appendix B for details. Estimates for panel a) and b) come from the third and fifth columns in Table 6 in Appendix B. 


\section{Conclusion}

Entering parenthood increases women's absence rate due to own sickness in relation to the corresponding rate for men. The effect is long-lasting: the gender gap remains as long as data allow us to follow the couples: up to 16 years after the arrival of the first child. Our main explanation for this effect is the unequal gender division of family responsibilities.

Women take a larger responsibility for the home production. This is a well established fact in the literature (Boye, 2008; Booth and Ours, 2005; Evertsson and Nermo 2007; Tichenor 1999). There are also studies showing that this unequal gender division emerges after entering parenthood (Van der Lippe and Siegers, 1994; Gauthier and Furstenberg, 2002). Mothers' larger family responsibility can affect their sickness absence in several ways.

We find no support for health deterioration among women after entering parenthood. Indeed, we find some evidence on the opposite, namely that in the long run, mothers' in-hospitalization rate decreases somewhat relative to that of fathers. This result supports the idea of Paringer, namely that households invest in the health of the main household producer. This is also in line with the fact that women outlive men. During the last 30 years, the gender gap in longevity has decreased in Sweden. ${ }^{25}$ An explanation could be a more equal gender division of household work and labour market work between men and women. ${ }^{26}$

We find some weak evidence that the effect of parenthood on sickness absence varies across women with different pre-birth incomes. This result supports the idea that women with different economic situations face different opportunities to reconcile the home-commitment and continue to work on the labour market and thereby face different incentives for using the sickness insurance.

Most significant for the magnitude of the effect is the female income trajectory since birth. Many mothers change their intensive-margin labour supply due to parenthood, particularly in Sweden where a lower labour

\footnotetext{
${ }^{25}$ According to data from Statistics Sweden: http: //www.scb.se/Pages/Article__-_333965.aspx.

${ }^{26}$ Survey data on the gender division of household work during the last 20 years support this idea to some extent. Also, men have increased their parental leave over time. Both observations could be seen as an indicator of a more equal gender division of the time spent on labour market work and household work.
} 
supply among parents is indirectly encouraged by the flexible and generous Swedish parental leave system. We find that mothers' income trajectory since giving birth is strongly related to the magnitude of the effect; the less favourable income trajectory, the more absent due to sickness. Mothers' labour supply is measured one year prior to sickness absence, and thus this result suggests that the lower labour supply induces more absence due to sickness rather than the other way round. Our interpretation of this result is that a lower labour supply induces a lower threshold for using the sickness insurance.

Finally, when entering parenthood, women fare worse in terms of labour market outcomes. However, women's choices, including higher sickness absence, might pay-off in health as suggested by Paringer (1983). ${ }^{27}$

\section{References}

Allen, S.G. (1981). "An empirical model of work attendance", Review of Economics and Statistics 63(1), pp. 77-87.

Åkerlind, I., K. Alexandersson, G. Hensing, M. Leijon, and P. Bjurulf (1996): "Sex differences in sickness absence in relation to parental status", Scandinavian Journal of Public Health, 24(1), 27-35.

Angelov, N., Johansson P., Lindahl, E. och Lindtröm, E-A. (2011) "Kvinnors och mäns sjukfrånvaro", IFAU-rapport 2011:2.

Angrist J D and Evans W N (1998) "Children and their parents' labor supply: evidence from exogenous variation in family size", American Economic Review, vol 88, nr 3, s 450-477.

Arrelöv, B., Edlund, C. and Goine, H. (2006) "Grindvakterna och sjukförsäkringen - samspel och motspel i SKA Projektet: Sjukförsäkring, kulturer och attityder". Edward Palmer (ed.),

Försäkringskassan (2011) Socialförsäkringen i siffror 2011 (in Swedish).

Baxter, J., Hewitt, B. and Haynes, M. (2008). "Life course transitions

\footnotetext{
${ }^{27}$ See also Lee (2010) for a discussion of gender differences in health related behaviour.
} 
and housework: Marriage, parenthood, and time on housework", Journal of Marriage and Family, 70, 259-272.

Booth, A.L. and Van Ours, J.C. (2005) "Hours of work and gender identity: Does part-time work make the family happier?", CEPR Discussion Paper No 5438, London.

Boschini, A., Håkansson C., Rosén, A. and Sjögren, A. (2011) "Trading off or having it all? Completed fertility and mid-career earnings of Swedish men and women", Working paper 2011:15, IFAU

Boye, K. (2008) "Happy hour? Studies on well-being and time spent on paid and unpaid work", Swedish Institute for Social Research Dissertation Series no. 74.

Bratberg. E, Dahl, S.A., and Risa, A.E. 2002. "The double burden Do combinations of career and family obligations increase sickness absence among women?", European Sociological Review, 18, 233-249.

Broström, G., P. Johansson, and M. Palme (2004) "Economic Incentives and Gender Differences in Work Absence Behavior", Swedish Economic Policy Review, 11, 33-63.

Burda, Michael, Daniel Hamermesh, and Philippe Weil. 2008. "The Distribution of Total Work in the EU and US.'In Working Hours and Job Sharing in the EU and USA: Are Europeans Lazy? Or Americans Crazy?, edited by Tito Boeri, Michael Burda, and Francis Kramarz. Oxford: Oxford University Press

Englund, L. (2001) "Förändringar i distriktsläkarnas sjukskrivningspraxis mellan åren 1996 och 2001 i ett svenskt landsting". Falun: Centrum för Klinisk Forskning Dalarna.

Engström P, Hesselius, P. and Persson, M. (2007), "Excess use of Temporary Parental Benefit", Working Paper 2007:18, IFAU.

Evertsson, M. and Nermo, M. (2007) "Changing Resources and the Division of Housework: A Longitudinal Study of Swedish Couples", European 
Sociological Review, 23: 455-470.

Gauthier, A. and Furstenberg, F.F. Jr. (2002) "The transition to adulthood: a time use perspective", The Annals of the American Academy of Political and Social Science March: 153-171

Gjerdingen, D. K. and Center, B. A. (2005). "First-time parents' postpartum changes in employment, childcare, and housework responsibilities", Social Science Research, 34, 103-116.

Hedborg, A. (2012) "Under höga tak ryms alla - en rapport om höjda tak i sjukförsäkringen", Kommunal produktion 2012.

Jacobsen J P, Wishart Pierce J and Rosenbloom J L (1999) "The effects of child-bearing on married women's labor supply and earnings" Journal of Human Resources, vol. 34, nr 3, s 449-474

Johansson, P. och M. Palme (1996). "Do Economic Incentives Affect Work Absence? Empirical Evidence Using Swedish Micro Data", Journal of Public Economics, 59, s. 195-218.

Johansson, P. och Palme, M. (2005) "Moral hazard and sickness insurance", Journal of Public Economics, vol 89, s 1879-1890

Kennerberg, L. (2007) "Hur förändras kvinnors och mäns arbetssituation när de får barn?", IFAU-rapport 2007:9. Institutet för arbetsmarknads- och utbildningspolitisk utvärdering, Uppsala.

Lee, C. (2010) "Gender, Health, and Health Behaviors", Ch. 20 in Chrisler, J.C. and McCreary D.R. (eds.), Handbook of Gender Research in Psychology, Springer Science.

Mastekaasa, A., and K. Olsen (2000): "Do women or Men have Less Healthy Jobs? An Analysis of Gender Differences in Sickness Absence", European Sociological Review, 16(3), 26786.

Mastekaasa, A., and K. Olsen (1998): "Gender, Absenteeism and Job Characteristics: A Fixed Effects Approach", Work and Occupations, 25, 195- 
2228.

Nathanson, C. (1975) "Illness and the feminine role: a theoretical review", Social science and medicine, vol 9, 57-62.

OECD (2010), "Gender Brief", OECD Social Policy Division.

OECD 2004 Employment Outlook 2004.

Paringer, (1983) "Women and Absenteeism: Health or Economics", American Economic Review, Vol. 73, No. 2, pp. 123-127

Persson, M (2011) "Substitution between temporary parental leave and sickness absence", Working Paper 2011:19 IFAU.

Sanchez, L. and Thomson, E. (1997). "Becoming mothers and fathers: Parenthood, gender, and the division of labor", Gender and Society, 11, 747-772.

SCB (2009) "Tid för vardagsliv - Kvinnors och mäns tidsanvändning 1990/91 och 2000/01", Levnadsförhållanden, rapport 99 Statistiska centralbyrån.

Selin, H. (2009) "The Rise in Female Employment and the Role of Tax Incentives. An Empirical Analysis of the Swedish Individual Tax Reform of 1971", UCFS Working Paper 2009:3.

SFS. Svensk författningssamling: Föräldraledighetslagen 1995:584.1995:584

Sindelar, Jody L. ""Differential Use of Medical Care by Sex.", J.P.E. 90 (October 1982): 1003-19.

SOU (2004): Den könsuppdelade arbetsmarknaden, Statens offentliga utredningar(SOU). Stockholm 2004:43.

The World Factbook (2012) Washington, DC: Central Intelligence Agency, 2012, accessed on February 18, 2013 from https : / www. cia.gov/library/ publications/the-world-factbook/index.html

Tichenor, V.J. (1999) "Status and Income as Gendered Resources: The 
Case of Marital Power", Journal of Marriage and Family, 61 638-650

U.S. Bureau of Labor Statistics (2011) "Women in the Labor Force: a Databook ", U.S. Department of Labor, Report 1034, December 2011

Van der Lippe, T. and Siegers, J. (1994) "Division of Household and Paid Labor between Partners: Effects of Relative Wage Rates and Social Norms", Kyklos, 47: 109-136.

Verbrugge, L. M. (1982) "Sex Differentials in Health", Public Health Report, 97, 417-437.

\section{Appendix A: Identification strategy}

Let $\left\{S_{j t}(1)\right\}_{t=1}^{T}, j=f, m$, be the potential sickness absence after becoming a parent in time period $t=0$ and let $\left\{S_{f t}(0)\right\}_{t=1}^{T}, j=f, m$, be the corresponding potential sickness absence if not becoming a parent. ${ }^{28}$ Furthermore let $\left\{s_{j t}\right\}_{t=-L}^{T}, j=f, m$, be the observed sickness absence stream since labour market entry which occurs $L$ periods before receiving the first child. The expectation that a couple has at $t=0$ regarding the withincouple sickness absence at time period $t>0$, for a couple that receives its first child at $t=0$, is defined as

$$
a_{t}=E_{t=0}\left\{\widetilde{Z}_{t}\right\}_{t=1}^{T}
$$

where

$$
\widetilde{Z}_{t}=\left(S_{f t}(1)-S_{m t}(1)\right)-\left(S_{f t}(0)-S_{m t}(0)\right) .
$$

The interest is in estimating the effect for those who become parents and since we sample parents, $S_{f t}(1)-S_{m t}(1)$ is observed, and so $S_{f t}(1)-$ $S_{m t}(1)=s_{f t}-s_{m t}$ for $t>0$. The main challenge therefore consists in estimating the within-couple differences in sickness absence in the absence of a child, i.e., $\left\{\left(S_{f t}(0)-S_{m t}(0)\right)\right\}_{t=1}^{T}$. This sequence obviously cannot be estimated without additional assumptions.

\footnotetext{
${ }^{28}$ For now, we keep the discussion general by not specifying whether $t$ indexes years or months. We are going to make the distinction at the end of the section, when the empirical specification is presented.
} 
To this end, assume that the potential difference in the absence of a child for $t>0$ is equal to the corresponding observed difference measured before parenthood and a stochastic term:

$$
\left(S_{f t}(0)-S_{m t}(0)\right)=\left(s_{f-1}-s_{m-1}\right)+\varepsilon_{t}, t>0 .
$$

where $\varepsilon_{t}$ is a random noise.

Our estimand is given as

$$
\alpha_{t}=E\left(a_{t} \mid \text { parent }=y e s\right)
$$

where the expectation is taken over the population of parents. Letting $i=1, \ldots, n$ index $n$ parents, for a given sample, a consistent estimator of the estimand (4) is given as

$$
\begin{aligned}
\widehat{\alpha}_{t} & =\frac{1}{n} \sum_{i=1}^{n}\left\{s_{i, f t}-s_{i, m t}-\left(s_{i, f-1}-s_{i, m-1}\right)\right\} \\
& =\frac{1}{n} \sum_{i=1}^{n} \widetilde{Z}_{i t}+\frac{1}{n} \sum_{i=1}^{n} \varepsilon_{i t},
\end{aligned}
$$

where in the last step, we use (2) and (3). Since $\varepsilon_{i t}, i=1, \ldots, n$, are random errors we get

$$
\operatorname{plim} \widehat{\alpha}_{t}=\alpha_{t}, t>0
$$

According to this set up, we are able to estimate the causal effect of entering parenthood on the within-couple female-male gap in sickness absence.

Note that the identifying assumption is that the expected potential gender gap in sickness absence in the absence of a child is constant for our population, that is

$$
E E_{t=0}\left(S_{f, t}(0)-S_{m, t}(0)\right)=E\left(s_{f,-1}-s_{m,-1}\right), t>0 .
$$

In the estimation, we use all available pre-child data instead of only one observation as in this expression. 


\section{Appendix B: Results on the role of economic incentives}

In the following we present heterogeneous effects depending on mothers' pre-birth income and the income trajectory after the arrival of the first child, based on the discussion in section 6.2. The results are presented in Table 6 . In order to have a reasonable measure of mothers' income trajectory, the estimates in Table 6 are based on a sample where the mothers' pre-birth income at $t=-2$ is higher than 50,000 SEK (approximately 4,500 EUR) measured in 2008 prices. The first column presents estimates from the baseline specification for this sample with the full set of controls. The estimates are close to the case with the full sample: for instance, the year 10 effect of parenthood is estimated at 0.642 sick days/month and the corresponding number for the baseline sample is 0.640 (see Table 3).

The rest of Table 6 presents heterogeneity analyses with respect to mothers' pre-child income (column 2), mothers' pre-child income in level and squared (column 3), mothers' income trajectory since before giving birth in levels (column 4), and in levels and, in order to take functional form assumption into account, squared (column 5). ${ }^{29}$ Below, we discuss the results in columns 3 and 5 , which both contain levels as well as squares of the interaction variables.

First, consider column 3 in Table 6 , where we empirically investigate whether the magnitude of the effect varies with a second-degree polynomial in mothers' pre-birth income level. Generally, the point estimates for the interaction term between the effect of parenthood and mothers' pre-child income have the expected negative sign, and some are statistically significant. For a particular year $j$ after child birth, these are the effects called year $j \times y_{-2}^{\text {mother }}$ in Table 6 . The estimates are very small (see also the graphical representation in section 6.3.2). The point estimates for the interaction between the effect of parenthood and mothers' pre-child income squared are statistically insignificant. These parameters are called year $j \times\left(y_{-2}^{\text {mother }}\right)^{2}$

\footnotetext{
${ }^{29}$ We have also estimated "non-parametric" models in which the pre-child incomes are included as factors in which the grouping are made on income quintiles. Results from this estimation are qualitatively the same as the results obtained from this parametric specification. The main advantage with the parametric specification is that it makes presentation of the results easier.
} 
in Table 6. Panel a) in Figure 6 in the main text is based on column 3 in Table 6: the baseline year 10 effect estimate of 1.654; the estimate of the interaction between pre-child income level and the year 10 effect of -0.00000770 ; and finally, the estimate of the interaction between pre-child income squared and the year 10 effect of $9.43 \mathrm{e}-12$.

Looking at our second hypothesis, namely whether the effect of parenthood is larger for mothers with low income trajectory, we check whether the magnitude of the effect of parenthood $t$ years after childbirth varies with mothers' income trajectory between year -2 (i.e., two years before giving birth) and year $j-1$ (i.e., the year before we measure sickness absence). The results from this analysis are presented in column 5, where we have included the level as well as the square of the interaction variable defined in terms of an income ratio. The interaction terms with the level year $j \times\left(\Delta_{j-1}\right)$ and square year $j \times\left(\Delta_{j-1}\right)^{2}$ of the interaction variable are both statistically and economically significant, for all years. Panel b) in Figure 6 in the main text is based on column 5 in Table 6: the baseline year 10 effect estimate of 2.562; the estimate of the interaction between $\Delta_{9}$ and the year 10 effect of 15.91; and finally, the estimate of the interaction between pre-child income squared and the year 10 effect of -18.08 . The empirical distribution of $\Delta_{9}$ also contains a mass at 0 , i.e., women that have withdrawn from the labour force in year 9 . Those observations are used in the estimation but not shown in the figure; for $\Delta_{9}$, the value of the effect is estimated at 2.562 . 
Table 6: Heterogeneity analysis with yearly effects for the sample of couples where $y_{-2}^{\text {mother }}>50,000$ SEK in order for $\Delta_{t-1}$ to be meaningful. $\left(\Delta_{t-1}=\left(y_{t-1}^{\text {mother }} / y_{-2}^{\text {mother }}\right)^{\frac{1}{t+1}}\right.$ with $t$ being time in years since birth.)

\begin{tabular}{|c|c|c|c|c|c|}
\hline & Baseline & Interaction, $y_{-2}^{\text {mother }}$ & Interaction, $\left(y_{-2}^{\text {mother }}\right)^{2}$ & Interaction, $\Delta_{t-1}$ & Interaction, $\Delta_{t-1}^{2}$ \\
\hline \multirow[t]{2}{*}{ intercept } & 0.0321 & 0.0335 & 0.0334 & 0.0329 & 0.0322 \\
\hline & $(0.0215)$ & $(0.0215)$ & $(0.0215)$ & $(0.0214)$ & $(0.0213)$ \\
\hline \multirow[t]{2}{*}{ pregnancy } & $1.770^{* * *}$ & $2.355^{* * *}$ & $2.390^{* * *}$ & $1.769^{* * *}$ & $1.756^{* * *}$ \\
\hline & $(0.0397)$ & $(0.119)$ & $(0.209)$ & $(0.0397)$ & $(0.0397)$ \\
\hline \multirow[t]{2}{*}{ year 1} & $-0.125^{* * *}$ & $-0.230^{* *}$ & -0.217 & $-0.126^{* * *}$ & $-0.139^{* * *}$ \\
\hline & $(0.0331)$ & $(0.0781)$ & $(0.133)$ & $(0.0330)$ & $(0.0330)$ \\
\hline \multirow[t]{2}{*}{ year 2} & $0.347^{* * *}$ & $0.318^{* *}$ & $0.518^{* *}$ & $0.342^{* * *}$ & $0.328^{* * *}$ \\
\hline & $(0.0417)$ & $(0.105)$ & $(0.175)$ & $(0.0416)$ & $(0.0416)$ \\
\hline \multirow[t]{2}{*}{ year 3} & $0.531^{* * *}$ & $0.642^{* * *}$ & $0.742^{* * *}$ & $0.689^{* * *}$ & $0.317^{* *}$ \\
\hline & $(0.0483)$ & $(0.117)$ & $(0.195)$ & $(0.0957)$ & $(0.110)$ \\
\hline \multirow[t]{2}{*}{ year 4} & $0.352^{* * *}$ & $0.545^{* * *}$ & $0.821^{* * *}$ & $0.711^{* * *}$ & $0.424^{* * *}$ \\
\hline & $(0.0532)$ & $(0.119)$ & $(0.197)$ & $(0.107)$ & $(0.120)$ \\
\hline \multirow[t]{2}{*}{ year 5} & $0.304^{* * *}$ & $0.604^{* * *}$ & $1.057^{* * *}$ & $1.383^{* * *}$ & $0.999^{* * *}$ \\
\hline & $(0.0605)$ & $(0.126)$ & $(0.212)$ & $(0.156)$ & $(0.177)$ \\
\hline \multirow[t]{2}{*}{ year 6} & $0.322^{* * *}$ & $0.656^{* * *}$ & $1.131^{* * *}$ & $2.085^{* * *}$ & $1.366^{* * *}$ \\
\hline & $(0.0721)$ & $(0.143)$ & $(0.238)$ & $(0.193)$ & $(0.209)$ \\
\hline \multirow[t]{2}{*}{ year 7} & $0.425^{* * *}$ & $0.778^{* * *}$ & $1.080^{* * *}$ & $2.573^{* * *}$ & $1.523^{* * *}$ \\
\hline & $(0.0848)$ & $(0.163)$ & $(0.261)$ & $(0.248)$ & $(0.265)$ \\
\hline year 8 & $0.471^{* * *}$ & $0.961^{* * *}$ & $1.095^{* * *}$ & $2.854^{* * *}$ & $1.522^{* * *}$ \\
\hline
\end{tabular}

Continued on Next Page... 
Table 6 - Continued

\begin{tabular}{|c|c|c|c|c|c|}
\hline & Baseline & Interaction, $y_{-2}^{\text {mother }}$ & Interaction, $\left(y_{-2}^{\text {mother }}\right)^{2}$ & Interaction, $\Delta_{t-1}$ & Interaction, $\Delta_{t-1}^{2}$ \\
\hline \multirow{3}{*}{ year 9} & $(0.0983)$ & $(0.176)$ & $(0.275)$ & $(0.278)$ & $(0.290)$ \\
\hline & $0.529^{* * *}$ & $1.196^{* * *}$ & $1.467^{* * *}$ & $3.879^{* * *}$ & $2.479^{* * *}$ \\
\hline & $(0.113)$ & $(0.186)$ & $(0.290)$ & $(0.329)$ & $(0.342)$ \\
\hline \multirow[t]{2}{*}{ year 10} & $0.642^{* * *}$ & $1.300^{* * *}$ & $1.654^{* * *}$ & $4.029^{* * *}$ & $2.562^{* * *}$ \\
\hline & $(0.127)$ & $(0.201)$ & $(0.305)$ & $(0.339)$ & $(0.346)$ \\
\hline \multirow[t]{2}{*}{ year 11} & $0.695^{* * *}$ & $1.497^{* * *}$ & $1.657^{* * *}$ & $4.146^{* * *}$ & $2.644^{* * *}$ \\
\hline & $(0.138)$ & $(0.216)$ & $(0.317)$ & $(0.352)$ & $(0.357)$ \\
\hline \multirow[t]{2}{*}{ year 12} & $0.761^{* * *}$ & $1.756^{* * *}$ & $1.746^{* * *}$ & $4.299^{* * *}$ & $2.930^{* * *}$ \\
\hline & $(0.149)$ & $(0.236)$ & $(0.353)$ & $(0.376)$ & $(0.380)$ \\
\hline \multirow[t]{2}{*}{ year 13} & $0.768^{* * *}$ & $1.488^{* * *}$ & $1.633^{* * *}$ & $3.562^{* * *}$ & $2.312^{* * *}$ \\
\hline & $(0.159)$ & $(0.244)$ & $(0.355)$ & $(0.392)$ & $(0.396)$ \\
\hline \multirow[t]{2}{*}{ year 14} & $0.821^{* * *}$ & $1.578^{* * *}$ & $1.772^{* * *}$ & $3.216^{* * *}$ & $2.020^{* * *}$ \\
\hline & $(0.169)$ & $(0.274)$ & $(0.418)$ & $(0.425)$ & $(0.429)$ \\
\hline \multirow[t]{2}{*}{ year 15} & $0.896^{* * *}$ & $1.584^{* * *}$ & $1.733^{* * *}$ & $3.445^{* * *}$ & $2.270^{* * *}$ \\
\hline & $(0.180)$ & $(0.314)$ & $(0.514)$ & $(0.466)$ & $(0.467)$ \\
\hline \multirow[t]{2}{*}{ year 16} & $0.918^{* * *}$ & $1.186^{* * *}$ & $1.272^{*}$ & $3.237^{* * *}$ & $2.145^{* * *}$ \\
\hline & $(0.193)$ & $(0.348)$ & $(0.586)$ & $(0.581)$ & $(0.585)$ \\
\hline \multirow[t]{2}{*}{ year 17} & $0.930^{* * *}$ & $1.009^{*}$ & 1.436 & $1.815^{*}$ & 0.944 \\
\hline & $(0.217)$ & $(0.443)$ & $(0.758)$ & $(0.744)$ & $(0.751)$ \\
\hline \multirow[t]{2}{*}{ pregnancy $\times y_{-2}^{\text {mother }}$} & & $-0.00000332^{* * *}$ & -0.00000370 & & \\
\hline & & $(0.000000608)$ & $(0.00000196)$ & & \\
\hline
\end{tabular}

Continued on Next Page... 
Table 6 - Continued

\begin{tabular}{|c|c|c|c|c|c|}
\hline & Baseline & Interaction, $y_{-2}^{\text {mother }}$ & Interaction, $\left(y_{-2}^{\text {mother }}\right)^{2}$ & Interaction, $\Delta_{t-1}$ & Interaction, $\Delta_{t-1}^{2}$ \\
\hline year $1 \times y_{-2}^{\text {mother }}$ & & $\begin{array}{c}0.000000634 \\
(0.000000390)\end{array}$ & $\begin{array}{l}0.000000503 \\
(0.00000132)\end{array}$ & & \\
\hline year $2 \times y_{-2}^{\text {mother }}$ & & $\begin{array}{c}0.000000187 \\
(0.000000538)\end{array}$ & $\begin{array}{l}-0.00000204 \\
(0.00000173)\end{array}$ & & \\
\hline year $3 \times y_{-2}^{\text {mother }}$ & & $\begin{array}{l}-0.000000623 \\
(0.000000592)\end{array}$ & $\begin{array}{l}-0.00000171 \\
(0.00000184)\end{array}$ & & \\
\hline year $4 \times y_{-2}^{\text {mother }}$ & & $\begin{array}{c}-0.00000111 \\
(0.000000589)\end{array}$ & $\begin{array}{l}-0.00000417^{*} \\
(0.00000188)\end{array}$ & & \\
\hline year $5 \times y_{-2}^{\text {mother }}$ & & $\begin{array}{c}-0.00000173^{* *} \\
(0.000000626)\end{array}$ & $\begin{array}{c}-0.00000678^{* *} \\
(0.00000207)\end{array}$ & & \\
\hline year $6 \times y_{-2}^{\text {mother }}$ & & $\begin{array}{l}-0.00000194^{* *} \\
(0.000000694)\end{array}$ & $\begin{array}{c}-0.00000722^{* *} \\
(0.00000220)\end{array}$ & & \\
\hline year $7 \times y_{-2}^{\text {mother }}$ & & $\begin{array}{c}-0.00000206^{* *} \\
(0.000000783)\end{array}$ & $\begin{array}{l}-0.00000536^{*} \\
(0.00000228)\end{array}$ & & \\
\hline year $8 \times y_{-2}^{\text {mother }}$ & & $\begin{array}{c}-0.00000287^{* * *} \\
(0.000000814)\end{array}$ & $\begin{array}{l}-0.00000425 \\
(0.00000231)\end{array}$ & & \\
\hline year $9 \times y_{-2}^{\text {mother }}$ & & $\begin{array}{c}-0.00000390^{* * *} \\
(0.000000810)\end{array}$ & $\begin{array}{c}-0.00000683^{* *} \\
(0.00000235)\end{array}$ & & \\
\hline year $10 \times y_{-2}^{\text {mother }}$ & & $\begin{array}{c}-0.00000388^{* * *} \\
(0.000000847)\end{array}$ & $\begin{array}{c}-0.00000770^{* *} \\
(0.00000244)\end{array}$ & & \\
\hline year $11 \times y_{-2}^{\text {mother }}$ & & $-0.00000474^{* * *}$ & $-0.00000637^{*}$ & & \\
\hline
\end{tabular}

Continued on Next Page... 
Table 6 - Continued

\begin{tabular}{|c|c|c|c|c|c|}
\hline & Baseline & Interaction, $y_{-2}^{\text {mother }}$ & Interaction, $\left(y_{-2}^{\text {mother }}\right)^{2}$ & Interaction, $\Delta_{t-1}$ & Interaction, $\Delta_{t-1}^{2}$ \\
\hline \multirow{3}{*}{ year $12 \times y_{-2}^{\text {mother }}$} & & $(0.000000879)$ & $(0.00000249)$ & & \\
\hline & & $-0.00000590^{* * *}$ & -0.00000561 & & \\
\hline & & $(0.000000979)$ & $(0.00000299)$ & & \\
\hline \multirow[t]{2}{*}{ year $13 \times y_{-2}^{\text {mother }}$} & & $-0.00000433^{* * *}$ & $-0.00000581^{*}$ & & \\
\hline & & $(0.000000975)$ & $(0.00000277)$ & & \\
\hline \multirow{2}{*}{ year $14 \times y_{-2}^{\text {mother }}$} & & $-0.00000457^{* * *}$ & -0.00000662 & & \\
\hline & & $(0.00000116)$ & $(0.00000356)$ & & \\
\hline \multirow[t]{2}{*}{ year $15 \times y_{-2}^{\text {mother }}$} & & $-0.00000420^{* *}$ & -0.00000575 & & \\
\hline & & $(0.00000140)$ & $(0.00000472)$ & & \\
\hline \multirow[t]{2}{*}{ year $16 \times y_{-2}^{\text {mother }}$} & & -0.00000178 & -0.00000260 & & \\
\hline & & $(0.00000156)$ & $(0.00000501)$ & & \\
\hline \multirow[t]{2}{*}{ year $17 \times y_{-2}^{\text {mother }}$} & & -0.000000688 & -0.00000546 & & \\
\hline & & $(0.00000210)$ & $(0.00000652)$ & & \\
\hline \multirow[t]{2}{*}{ pregnancy $\times\left(y_{-2}^{\text {mother }}\right)^{2}$} & & & $9.11 \mathrm{e}-13$ & & \\
\hline & & & $(4.51 \mathrm{e}-12)$ & & \\
\hline \multirow[t]{2}{*}{ year $1 \times\left(y_{-2}^{\text {mother }}\right)^{2}$} & & & $2.95 \mathrm{e}-13$ & & \\
\hline & & & $(3.33 \mathrm{e}-12)$ & & \\
\hline \multirow[t]{2}{*}{ year $2 \times\left(y_{-2}^{\text {mother }}\right)^{2}$} & & & $5.47 \mathrm{e}-12$ & & \\
\hline & & & $(4.34 \mathrm{e}-12)$ & & \\
\hline \multirow[t]{2}{*}{ year $3 \times\left(y_{-2}^{\text {mother }}\right)^{2}$} & & & $2.67 \mathrm{e}-12$ & & \\
\hline & & & $(4.42 \mathrm{e}-12)$ & & \\
\hline
\end{tabular}

Continued on Next Page... 
Table 6 - Continued

\begin{tabular}{|c|c|c|c|c|c|}
\hline & Baseline & Interaction, $y_{-2}^{\text {mother }}$ & Interaction, $\left(y_{-2}^{\text {mother }}\right)^{2}$ & Interaction, $\Delta_{t-1}$ & Interaction, $\Delta_{t-1}^{2}$ \\
\hline \multirow[t]{2}{*}{ year $4 \times\left(y_{-2}^{\text {mother }}\right)^{2}$} & & & $7.56 \mathrm{e}-12$ & & \\
\hline & & & $(4.58 \mathrm{e}-12)$ & & \\
\hline \multirow{2}{*}{ year $5 \times\left(y_{-2}^{\text {mother }}\right)^{2}$} & & & $1.25 \mathrm{e}-11^{*}$ & & \\
\hline & & & $(5.12 \mathrm{e}-12)$ & & \\
\hline \multirow[t]{2}{*}{ year $6 \times\left(y_{-2}^{\text {mother }}\right)^{2}$} & & & $1.31 \mathrm{e}-11^{*}$ & & \\
\hline & & & $(5.27 \mathrm{e}-12)$ & & \\
\hline \multirow[t]{2}{*}{ year $7 \times\left(y_{-2}^{\text {mother }}\right)^{2}$} & & & $8.15 \mathrm{e}-12$ & & \\
\hline & & & $(5.14 \mathrm{e}-12)$ & & \\
\hline \multirow[t]{2}{*}{ year $8 \times\left(y_{-2}^{\text {mother }}\right)^{2}$} & & & $3.40 \mathrm{e}-12$ & & \\
\hline & & & $(4.97 \mathrm{e}-12)$ & & \\
\hline \multirow[t]{2}{*}{ year $9 \times\left(y_{-2}^{\text {mother }}\right)^{2}$} & & & $7.21 \mathrm{e}-12$ & & \\
\hline & & & $(4.69 \mathrm{e}-12)$ & & \\
\hline \multirow[t]{2}{*}{ year $10 \times\left(y_{-2}^{\text {mother }}\right)^{2}$} & & & $9.43 \mathrm{e}-12$ & & \\
\hline & & & $(5.00 \mathrm{e}-12)$ & & \\
\hline \multirow[t]{2}{*}{ year $11 \times\left(y_{-2}^{\text {mother }}\right)^{2}$} & & & $4.02 \mathrm{e}-12$ & & \\
\hline & & & $(5.09 \mathrm{e}-12)$ & & \\
\hline \multirow[t]{2}{*}{ year $12 \times\left(y_{-2}^{\text {mother }}\right)^{2}$} & & & $-7.46 \mathrm{e}-13$ & & \\
\hline & & & $(6.79 \mathrm{e}-12)$ & & \\
\hline \multirow[t]{2}{*}{ year $13 \times\left(y_{-2}^{\text {mother }}\right)^{2}$} & & & $3.73 \mathrm{e}-12$ & & \\
\hline & & & $(5.58 \mathrm{e}-12)$ & & \\
\hline year $14 \times\left(y_{-2}^{\text {mother }}\right)^{2}$ & & & $5.25 \mathrm{e}-12$ & & \\
\hline
\end{tabular}

Continued on Next Page... 
Table 6 - Continued

\begin{tabular}{|c|c|c|c|c|c|}
\hline & Baseline & Interaction, $y_{-2}^{\text {mother }}$ & Interaction, $\left(y_{-2}^{\text {mother }}\right)^{2}$ & Interaction, $\Delta_{t-1}$ & Interaction, $\Delta_{t-1}^{2}$ \\
\hline \multirow{3}{*}{ year $15 \times\left(y_{-2}^{\text {mother }}\right)^{2}$} & & & $(8.05 \mathrm{e}-12)$ & & \\
\hline & & & $3.98 \mathrm{e}-12$ & & \\
\hline & & & $(1.13 \mathrm{e}-11)$ & & \\
\hline \multirow[t]{2}{*}{ year $16 \times\left(y_{-2}^{\text {mother }}\right)^{2}$} & & & $2.09 \mathrm{e}-12$ & & \\
\hline & & & $(1.04 \mathrm{e}-11)$ & & \\
\hline \multirow[t]{2}{*}{ year $17 \times\left(y_{-2}^{\text {mother }}\right)^{2}$} & & & $1.24 \mathrm{e}-11$ & & \\
\hline & & & $(1.33 \mathrm{e}-11)$ & & \\
\hline \multirow[t]{2}{*}{ year $3 \times \Delta_{t-1}$} & & & & $-0.216^{*}$ & $2.085^{* * *}$ \\
\hline & & & & $(0.104)$ & $(0.338)$ \\
\hline \multirow[t]{2}{*}{ year $4 \times \Delta_{t-1}$} & & & & $-0.470^{* * *}$ & $1.374^{* * *}$ \\
\hline & & & & $(0.114)$ & $(0.366)$ \\
\hline \multirow[t]{2}{*}{ year $5 \times \Delta_{t-1}$} & & & & $-1.290^{* * *}$ & $1.498^{* *}$ \\
\hline & & & & $(0.162)$ & $(0.515)$ \\
\hline \multirow[t]{2}{*}{ year $6 \times \Delta_{t-1}$} & & & & $-2.016^{* * *}$ & $4.229^{* * *}$ \\
\hline & & & & $(0.192)$ & $(0.669)$ \\
\hline \multirow[t]{2}{*}{ year $7 \times \Delta_{t-1}$} & & & & $-2.412^{* * *}$ & $7.604^{* * *}$ \\
\hline & & & & $(0.241)$ & $(0.860)$ \\
\hline \multirow[t]{2}{*}{ year $8 \times \Delta_{t-1}$} & & & & $-2.653^{* * *}$ & $11.44^{* * *}$ \\
\hline & & & & $(0.264)$ & $(0.998)$ \\
\hline \multirow[t]{2}{*}{ year $9 \times \Delta_{t-1}$} & & & & $-3.682^{* * *}$ & $12.91^{* * *}$ \\
\hline & & & & $(0.310)$ & (1.189) \\
\hline
\end{tabular}

Continued on Next Page... 
Table 6 - Continued

\begin{tabular}{|c|c|c|c|c|c|}
\hline & Baseline & Interaction, $y_{-2}^{\text {mother }}$ & Interaction, $\left(y_{-2}^{\text {mother }}\right)^{2}$ & Interaction, $\Delta_{t-1}$ & Interaction, $\Delta_{t-1}^{2}$ \\
\hline year $10 \times \Delta_{t-1}$ & & & & $\begin{array}{c}-3.723^{* * *} \\
(0.313)\end{array}$ & $\begin{array}{c}15.91^{* * *} \\
(1.281)\end{array}$ \\
\hline year $11 \times \Delta_{t-1}$ & & & & $\begin{array}{c}-3.796^{* * *} \\
(0.322)\end{array}$ & $\begin{array}{c}19.04^{* * *} \\
(1.425)\end{array}$ \\
\hline year $12 \times \Delta_{t-1}$ & & & & $\begin{array}{c}-3.894^{* * *} \\
(0.341)\end{array}$ & $\begin{array}{c}19.42^{* * *} \\
(1.602)\end{array}$ \\
\hline year $13 \times \Delta_{t-1}$ & & & & $\begin{array}{c}-3.122^{* * *} \\
(0.351)\end{array}$ & $\begin{array}{c}21.31^{* * *} \\
(1.795)\end{array}$ \\
\hline year $14 \times \Delta_{t-1}$ & & & & $\begin{array}{c}-2.720^{* * *} \\
(0.384)\end{array}$ & $\begin{array}{c}23.76^{* * *} \\
(2.166)\end{array}$ \\
\hline year $15 \times \Delta_{t-1}$ & & & & $\begin{array}{c}-2.902^{* * *} \\
(0.426)\end{array}$ & $\begin{array}{c}24.19^{* * *} \\
(2.550)\end{array}$ \\
\hline year $16 \times \Delta_{t-1}$ & & & & $\begin{array}{c}-2.673^{* * *} \\
(0.543)\end{array}$ & $\begin{array}{c}21.75^{* * *} \\
(3.068)\end{array}$ \\
\hline year $17 \times \Delta_{t-1}$ & & & & $\begin{array}{l}-1.190 \\
(0.712)\end{array}$ & $\begin{array}{c}18.73^{* * *} \\
(4.491)\end{array}$ \\
\hline year $3 \times \Delta_{t-1}^{2}$ & & & & & $\begin{array}{c}-2.020^{* * *} \\
(0.272)\end{array}$ \\
\hline year $4 \times \Delta_{t-1}^{2}$ & & & & & $\begin{array}{c}-1.643^{* * *} \\
(0.299)\end{array}$ \\
\hline year $5 \times \Delta_{t-1}^{2}$ & & & & & $-2.484^{* * *}$ \\
\hline
\end{tabular}

Continued on Next Page... 
Table 6 - Continued

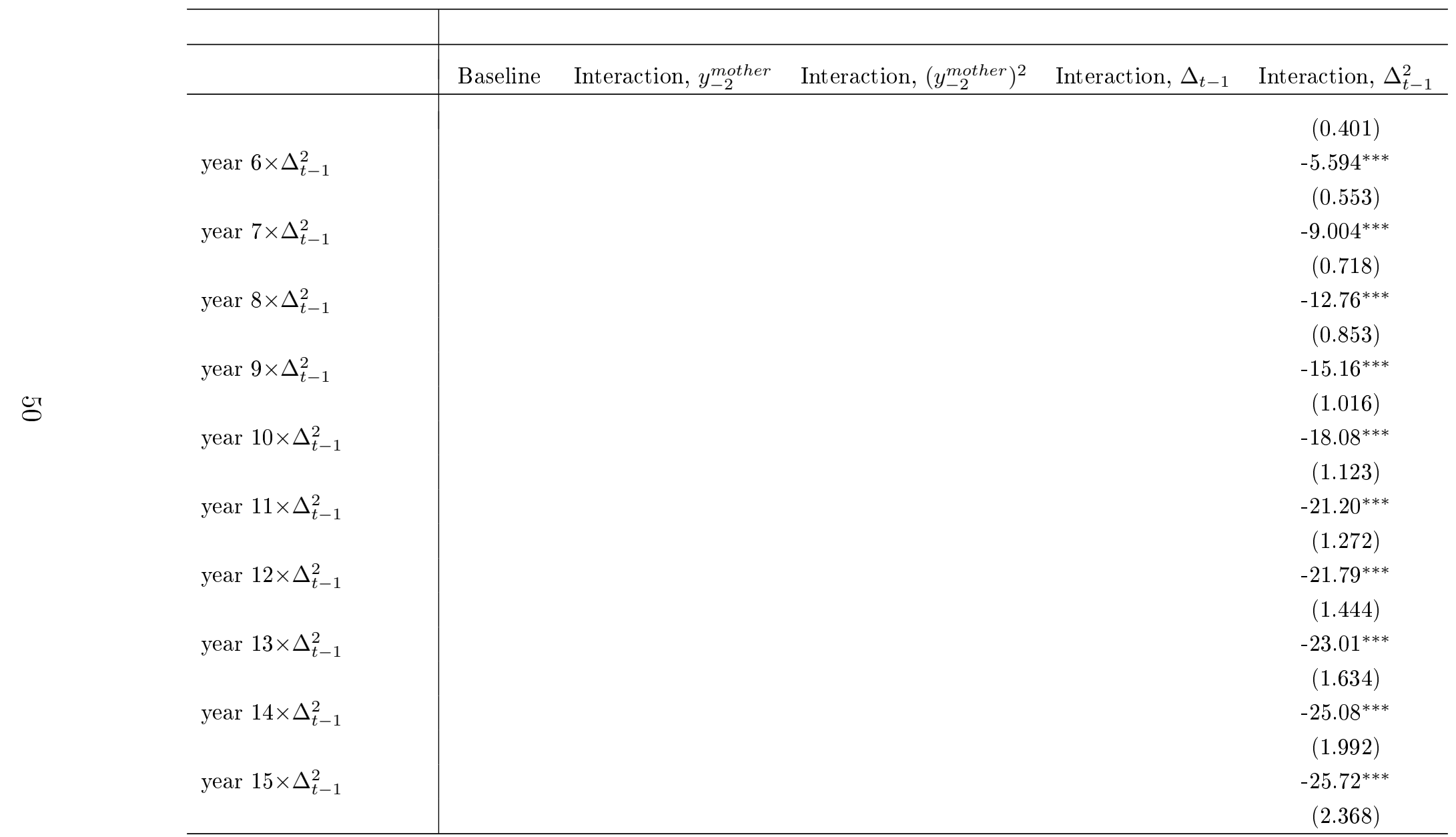

Continued on Next Page... 
Table 6 - Continued

\begin{tabular}{|c|c|c|c|c|c|}
\hline & Baseline & Interaction, $y_{-2}^{\text {mother }}$ & Interaction, $\left(y_{-2}^{\text {mother }}\right)^{2}$ & Interaction, $\Delta_{t-1}$ & Interaction, $\Delta_{t-1}^{2}$ \\
\hline \multirow[t]{2}{*}{ year $16 \times \Delta_{t-1}^{2}$} & & & & & $-23.23^{* * *}$ \\
\hline & & & & & $(2.837)$ \\
\hline \multirow{2}{*}{ year $17 \times \Delta_{t-1}^{2}$} & & & & & $-19.06^{* * *}$ \\
\hline & & & & & $(4.167)$ \\
\hline$N$ & $4,319,772$ & $4,319,772$ & $4,319,772$ & $4,319,772$ & $4,319,772$ \\
\hline$R^{2}$ & 0.008 & 0.008 & 0.008 & 0.014 & 0.024 \\
\hline $\operatorname{adj} . R^{2}$ & 0.008 & 0.008 & 0.008 & 0.014 & 0.023 \\
\hline
\end{tabular}

er Notes: Standard errors are reported in parentheses and clustered at couple level. Significance levels are denoted by ${ }^{*}(\mathrm{p}<0.05),{ }^{* *}(\mathrm{p}<0.01)$, and *** $(\mathrm{p}<0.001)$. The regressions include calender year dummies, age difference, and pre-child controls for differences in income and education. 